\title{
DREPTUL LA APEL CĂTRE SFÂNTUL SCAUN, AL INSTITUȚIILOR ECLEZIASTICE DIN TRANSILVANIA, ÎN SECOLUL AL XIII-LEA
}

\author{
THE RIGHT TO APPEAL TO HOLLY SEE IN XIII CENTURY. \\ THE CASE OF ECLESSIASTICAL INSTITUTIONS \\ IN TRANSYLVANIA
}

\author{
DOI:10.24193/SUBBiur.63(2018).1.3 \\ Published Online: 2018-03-20 \\ Published Print: 2018-03-30
}

\section{Tudor ŞTEFĂNESCU*}

\begin{abstract}
The aim of this article is to underline the development and the use of the right of appeal to the Pontifical Court, in the kingdom of Hungary, especially in the east region of Transylvania in the XIII century.

The right of appeal as a branch of roman law, was studied and put in practice in a rigorous way, for the first time in the XII century, in Italian space, as a part of the medieval cultural phenomenon called The Renaissance of Roman Law. The right of appeal has been introduced in the canon law, therefore the clerics, who were discontent with the sentences issued in local trials, have received the right to appeal to the supreme judgement of the Holly See.

In the XIII century, in the epoch of hierocracy, the canon law, including the right of appeal became universal law. Particularly, pope Innocent III, in 1198 offers for the first time the right of appeal to bishop of Transylvania. Therefore, during XIII century, the bishops together with other eclesiastical institutions of Transylvania as chapters and abbeys use the right of appeal to Holly See. As a consequence, the Apostolic See interferes more than 40 times in the internal affairs of eclesiastical institutions and that means a strong connection between Transylvania, the eastern part of Societas Christiana and Rome.
\end{abstract}


Rezumat: În Evul Mediu, credința este valoarea comună care îi unește pe oameni într-o comunitate specifică numită Societas Christiana sau Christianitas. Mai mult, între secolele al XI-lea şi al XIII-lea, este inserat şi dreptul în această ecuație a unității, așadar Societas Christiana devine o unitate prin credință, printrun drept comun universal și prin instituții specifice. Toate aceste elemente le regăsim din secolul al XIII-lea și în regatul maghiar, inclusiv în Transilvania.

Din secolul al XIII-lea, dar cu precădere în secolul al XIII-lea, spaţiul periferic transilvănean se conectează la realitățile canonice din Occident prin infiltrarea ordinelor monahale centralizate, ce implică ingerința Sfântului Scaun în această zonă. În plus noi adăugăm încă un instrument de conexiune, anume dreptul instituțiilor ecleziastice de a apela la Scaunul Apostolic, care se definește ca instanță supremă de judecată. $\mathrm{Cu}$ toate că Transilvania este o regiune periferică în Christianitas, ea se adaptează prin faptul că asimilează principiile de drept roman în chestiunea judecării proceselor ecleziastice. În acest fel semnalăm, în această zonă, începând cu anul 1199, existența unui fenomen juridic viu și complex a cărui analiză ne ajută să cunoaștem cu o mai mare claritate realitățile din Transilvania în secolul al XIII-lea. Înainte de a discuta despre chestiunea apelului în Transilvania, dorim să clarificăm în câteva cuvinte originea și evoluția legislației acestui instrument la nivel european, în secolele al XII-lea și al XIII-lea.

Keywords: right to appeal under Canon Law, eclesiastical institutions, Canon Law, Middle Ages, Medieval Transylvania, Holly See

Cuvinte cheie: apelurile în dreptul canonic, instituții ecleziastice, Drept canonic, Evul Mediu, Transilvania medievală, Sfantul Scaun

\section{Evoluția canoanelor privind apelul la Sfântul Scaun}

În arcul de timp cuprins între secolele al XI-lea și al XIII-lea, în sânul civilizației creștine latine se produce un fenomen amplu și complex numit de către unii istorici „renaşterea juridică” ${ }^{1}$. În linii generale fenomenul are cauze economice $^{2}$, culturale 3 și în special teologico-politice4.

În primul mileniu creștin rezoluțiile conciliare, intervențiile pontificale și scrierile patristice au reprezentat formele de autoritate în materie de drept canonic. Ele se sistematizează într-un corpus de legi amplu și riguros structurat, doar în secolul al XIII-lea, sub umbrela Bisericii Romane, cu ajutorul instrumentelor oferite de dreptul antic roman. 
Acest proces de metabolizare a dreptului roman, în vederea forjării celui canonic, a necesitat o putere instituțională remarcabilă de care Biserica Romană a dat dovadă, în urma unui lung proces de reformă început din a doua jumătate a secolului al XI-lea, prin lansarea tezelor hierocratice de Papa Grigore al VII-lea şi continuată ulterior de pontifii din secolele al XII-lea și al XIII-lea ${ }^{5}$ Importante personaje pe tronul pontifical, precum Inocențiu al II-lea (1130-1143), Alexandru al III-lea (1159-1181), Inocențiu al III-lea (1198-1216) sau Grigore al IX-lea (1227-1241), au adus propriile contribuții prin promulgarea colecțiilor de drept canonic și prin sprijinirea renașterii studiului dreptului roman.

Din punct de vedere metodologic, cele mai importante colecții de decretale $^{6}$ din secolele al XII-lea şi al XIII-lea sunt sistematizate și ordonate după modelul oferit de Codul lui Iustinian. În acelaşi timp, numeroase principii din dreptul roman, alături de dreptul de apel și regulile de procedură necesare pentru un proces de judecată bazat pe rațiune, nu pe arbitrariu, sunt inserate în colecțiile de drept canonic și aplicate în tribunalele ecleziastice 7 . Astfel prin promulgarea de către Suveranul Pontif a acestor colecții de drept canonic în secolele al XII-lea și al XIII-lea, principiile de drept roman mai sus menționate sunt aplicate în mod universal.

În epoca medievală, canoanele privind dreptul la apel se creionează în funcție de modelul oferit de legislația apelului existentă în constituțiile imperiale antice. Principalele școli de drept din secolele al XI-lea, al XII-lea şi al XIII-lea: cea din Provence, Pavia sau Bologna, au abordat din propriul punct de vedere această legislație însă, în expunerea ce urmează, ne vom referi la cea mai faimoasă universitate medievală: cea din Bologna ${ }^{8}$.

Singura sursă a dreptului la apel la care juriștii bolonezi, numiți glosatori ${ }^{9}$ se raportează, în secolele al XII-lea și al XIII-lea este cea din Corpusul de legi ${ }^{10}$ publicat de împăratul Iustinian în 534, care la rândul său își trage seva din constituțiile imperiale din secolul al IV-lea. Glosatorii nu aduc un consistent surplus de originalitate în interpretarea legilor referitoare la apel, ci jonglează cu numeroase amendări pentru a limita sau a extinde dreptul la recurs, în funcție de fiecare situație în parte ${ }^{11}$. Totuși, direcția generală de interpretare a înclinat către utilizarea acestuia în primul rând ca un veritabil instrument de opoziție împotriva sentințelor judecătorilor considerate a fi nedrepte, injuste sau abuzive $^{12}$. 
Juriștii Școlii lui Irnerius din Bologna ${ }^{13}$, care au scris primele tratate influențate de dreptul roman în a doua jumătate a secolului al XII-lea, au evidențiat în cazul legislației apelului diverse aspecte importante. În schimb, în acest articol vom analiza doar acele aspecte care se reflectă și în cazurile transilvănene.

\section{Apelul la instanța supremă de judecată}

De-a lungul istoriei imperiului roman, instanța supremă de judecată a fost reprezentată de împărat. În Orient, împăratul își va consolida acest drept inclusiv de-a lungul Evului Mediu, în timp ce în Occident, din 475-476 d.Hr., autoritatea centrală imperială se va dizolva. Din acest motiv, în Apusul Europei, Biserica Romană va reprezenta liantul comun al popoarelor creștine, iar instituția Sfântului Scaun va îngloba autoritatea judecătorească supremă în plan spiritual și temporal în apogeul epocii hierocratice ${ }^{14}$.

Istoricii au observat că din secolul al IV-lea, împărații romani reformează legislația apelului pe tot cuprinsul imperiului și își afirmă autoritatea de judecători supremi. Constituțiile imperiale menționează, în primul rând, dreptul litiganților de a apela instanța imperială ${ }^{15}$, în cazul în care procesul se blochează sau sentința este considerată incorectă. Ulterior, din secolul al VI-lea, juriștii lui Iustinian vor augmenta puterea judecătorească a împăratului ${ }^{16}$.

În ceea ce privește intervenția imperială în procesele locale, atât litiganții, cât și judecătorii locali aflați într-o dificultate în timpul proceselor, aveau dreptul de a solicita împăratului explicații (lat. consultatio) ${ }^{17}$ de natură juridică. Acesta le răspundea prin emiterea decretalelor imperiale care primeau greutatea unei legi incontestabile și a unei sentințe definitive. ${ }^{18}$

În secolele al IV-lea și al V-lea, Biserica devine una din cele mai importante instituţii ale Imperiului Roman. Ea se structurează și se organizează pe baza noului drept canonic a cărui autoritate este dată de conciliile ecumenice prezidate de împărați. Noul dreptul canonic este structurat, la rândul său, pe baza dreptului roman, preluând numeroase influențe din partea acestuia, printre care și dreptul la apel față de instanța de judecată superioară. Chestiunea dreptului de apel la instanța eclesiastică supremă s-a conturat sub formă de canoane în secolul al IV-lea. Mai exact, sinodul din Serdica, din $343^{19}$, a emis 
o serie de canoane prin care a afirmat, pentru prima oară, funcția Romei ca și Curte de apel ${ }^{20}$. Ulterior, canoanele sinodului de la Serdica, au fost confirmate de împărații Gratianus și Valentinianus al II-lea în 378 respectiv 379.

Mai mult, Primatul Apostolic este reafirmat, în a doua jumătate a secolului al IV-lea și consolidat de către autoritatea imperială. În situația alegerii a doi pontifi de către clerul roman, împăratul Gratianus aprobă cererea papei Damasus I(366-384) de a-l condamna pe cel de-al doilea papă în funcție, Ursinus şi pe adepții săi. Damasus I rămâne astfel singurul pontif recunoscut de împărat, împreună cu atributele sale de judecător suprem ${ }^{21}$ prin urmare Curtea de apel romană devine cea mai înaltă curte de judecată a Bisericii. De asemenea în timpul acestui pontif, se utilizează, în documente, expersia Sedes Apostolica $^{22}$, cu referință la Scaunul Apostolului Petru și tradiția petrină.

În anul 395, împăratul Theodosius împarte imperiul, din punct de vedere administrativ, în două părți: Imperiul Oriental, cu capitala la Constantinopol şi cel Occidental având capitala la Roma/Ravena. De-a lungul secolului al V-lea autoritatea directă a Romei asupra provinciilor va fi tot mai instabilă, cu toate că între anii 418-432 suveranii pontifi intervin activ în afacerile episcopiilor africane în urma apelurilor acestora ${ }^{23}$.

În Orient în schimb, Constantinopolul își va consolida autoritatea politică și militară, în timp ce Biserica Ortodoxă Constantinopolitană se va impune, la rândul ei, în faţa altor Biserici Orientale. În acest context, sinodul de la Chalcedon, din 451 va ridica instanța episcopală din Constantinopol la rangul de Curte de apel ${ }^{24}$.

În Occident, episcopul Romei (Papa) își va menține titulatura de Primatus în faţa altor episcopi în virtutea faptului că este urmaşul Apostolului Petru, primul episcop al creștinilor din Roma. De-a lungul primului mileniu creștin, primatul Scaunului Apostolic va fi afirmat, în repetate rânduri, de la Grigore cel Mare (540-604) la Leon al III-lea (sec.VIII) şi Ioan al XII-lea (930-964).

La începutul celui de-al doilea mileniu creștin, respectiv în a doua jumătate a secolului al XI-lea are loc marea reformă pontifului Grigore al VIIlea care a stabilit, printre altele, următoarele: superioritatea Sfântului Scaun în fața puterilor seculare, autoritatea judecătorească supremă a Suveranului Pontif, reforma monahismului și a clerului ${ }^{25}$. 
Consecințele reformei gregoriene se manifestă deja, în secolul al XII-lea, prin sistematizarea și publicarea unor faimoase și riguroase opere de drept canonic. Spre exemplu, canonistul Gratianus, în lucrarea sa numită Decretum, din 1140, una din cele mai importante opere de drept din Evul Mediu, subliniază puterea judecătorească a pontifului prin inserarea canonului trei al sinodului de la Serdica, acesta fiind considerat o sursă de autoritate canonică. Ulterior, canonul trei va fi inserat şi în alte opere juridice din secolul al XII-lea ${ }^{26}$,

În acest timp, în paralel cu activitatea de comentare a canoanelor, juriștii bolonezi Irnerius, Albericus, Piacentino și Giovanni Bassiano, analizează corpus-ul de legi a lui Iustinian. În paginile acestuia, ei interpretat apelul la instanța supremă subliniind, la rândul lor, caracterul definitiv al sentinței imperiale și superioritatea sa în raport cu legea existentă cu care s-ar afla în contradicție (ce devine automat nulă). Cu toate acestea, există și posibilitatea ca apelul să fie înaintat de litiganți înainte de sentința finală. ${ }^{27}$

De asemenea, juriștii sus amintiți validează posibilitatea litiganților și a judecătorilor locali de a solicita explicații juridice judecătorului suprem. Aici menționăm că poziția de judecător suprem, pe care o deținea împăratul roman, este arogată de către Suveranul Pontif, în Evul Mediu, în chestiuni spirituale şi ulterior chiar temporale ${ }^{28}$. In acest fel, din secolul al XII-lea, pontiful își arogă dreptul de a oferi explicații de natură juridică (numite consultatio) solicitărilor episcopilor (judecătorii eclesiastici locali).

\section{Interzicerea apelului}

În secolul al IV-lea, dreptului de apel ${ }^{29}$ i se impun o serie de limite în funcţie de diverse contexte economice şi sociale. Aici vom enumera doar două: pe de o parte împărații interzic, în mod repetitiv și sever, apelul în cazul sentințelor pentru condamnarea infracțiunilor și, pe de altă parte, în cazul sentințelor pentru condamnarea celor ce au datorii financiare față de fisc. $3^{30}$ În primul caz, constituțiile împăraților Constans al II-lea și Constantin, reformulate ulterior și adăugate în Codul lui Iustinian, prevăd interzicerea apelului în cazul sentințelor ce condamnă infracțiuni precum: crimă, adulter, otrăvire, vrăjitorie și violență ${ }^{31}$, dacă sunt însoțite de probe. 
În secolul al XII-lea și al XIII-lea, juristul Irnerius și urmașii săi: Piacentino, Giovanni Bassiano, Bulgarus, Azzonis sau Accurssius conexează interzicerea apelului cu diverse situații în funcție de propria interpretare a textului antic. Subliniem aici trei cazuri:

1. Interdicția în cazul sentinței temporale: în cazul unor situații neprevăzute, a neînțelegerilor privind aplicarea regulilor de procedură, devine necesară emiterea unei sentințe interlocutorii sau temporare inapelabile pentru ca procesul să nu se blocheze 32 .

2. Interzicerea apelului în cazul sentințelor pentru condamnarea păcatelor.

În fapt, aceasta preia legea romană ce interzice apelul în cazul anumitor infracțiuni și o adaptează contextului medieval. Noi considerăm că aici se observă elementul original al gândirii juridice creștine, prin fuziunea între principiile morale și caracterul riguros al dreptului roman. Spre exemplu, în urma metabolizării dreptului penal roman în dreptul canonic, păcatele grave (conform moralei creștine) precum crima, furtul, incestul, bigamia, vrăjitoria, violența, adulterul etc. devin infracțiuni care trebuie pedepsite.

În Codul lui Iustinian33, tributar dreptului antic, mărturia era considerată o probă suficientă pentru emiterea unei sentințe definitive în cazul infracțiunilor amintite, cu excepția mărturiei prin tortură. În schimb, din secolul al XII-lea, la Școala din Bologna, Irnerius trasează o altă direcție de interpretare a legii apelului, susținând că mărturia poate fi eronată, așadar sentința de condamnare poate fi apelabilă ${ }^{34}$.Este posibil ca interpretarea lui Irnerius să se datoreze influenței unei tradiții medievale timpurii, datată în Decretalele episcopului Isidor din Sevilia (sec.al IX-lea) 35 şi în Dictatus Papae, scrisoarea pontifului Grigore al VII-lea (sec.al XI-lea) ce accentuau autoritatea dreptului la apel ${ }^{36}$.

3. Este permis a fi înaintat apelul împotriva a două sentințe maximum. Este important acest aspect deoarece vom vedea că interzicerea celui de-al treilea apel în acelaşi proces (ce implică sentința definitivă) se aplică inclusiv în regiunea estică a regatului maghiar, Transilvania, respectiv într-un proces, din 1232, dintre canonicii capitlului din Oradea și abatele Benedict, lector de Strigoniu. 


\section{Apelul în cazul litigiilor privind dreptul asupra posesiunilor}

În această chestiune, o constituție emisă în 386 , reluată ulterior în Codul lui Iustinian ${ }^{37}$, a reprezentat reperul cel mai important pentru juriștii din Școala lui Irnerius. Conform acesteia, într-un proces privind posesia imobilelor, înaintarea apelului de către una din părți nu poate să oprească execuția sentinței finale. Mai mult, în cazul intrării în posesia unor bunuri prin violență, actul în sine era pedepsit prin confiscarea acestora, iar violența fiind considerată o infracțiune, se pedepsea printr-o sentință inapelabilă.

În cea mai mare parte, glosatorii din Bologna, au interpretat această lege romană în acord cu faptul că, în cazul litigiilor privind posesia bunurilor și proprietăților, apelul este interzis ${ }^{3}{ }^{8}$. Totuşi, unul dintre juriști, Jacopo Baldovini a criticat legea și a completat-o introducând posibilitatea apelului cu rezerva faptului că acesta nu are neapărat un efect de suspendare a sentinței finale 39 .

\section{Apelul în procesele implicând episcopia}

Împăratul Constantin este primul care formulează o legislație oficială privind funcționarea tribunalelor ecleziastice în $314^{40}$. În cele din urmă, în anul 408 Theodosius al II-lea oferă episcopului dreptul de a emite o sentință inapelabilă. Legislația se va îmbogăți în secolele următoare, cu precădere în Imperiul Roman de Răsărit, unde juriștii acordă o atenție sporită dreptului la apel în procesele ecleziastice. Cea mai importantă reformă în acest sens îi aparține împăratului Iustinian și constă în validarea apelului în urma sentinței episcopale.

În cadrul Școlii din Bologna, interpretările cu privire la competența episcopului de a emite o sentință apelabilă sau definitivă au variat. Pe de o parte, Piacentinus preia reformele lui Iustinian și, mai mult, extinde competențele judecătorului secular în fața episcopului ${ }^{41}$.

În schimb, Azzonis ${ }^{42}$ susține că apelabilitatea sau inapelabilitatea sentinței episcopale este relativă. Așadar episcopul are dreptul să judece atât o cauză ecleziastică cât și o cauză civilă, dar în condițiile în care cele două părți apelează voluntar la judecata sa, sentința devine definitivă. Însă dacă judecata episcopului este impusă, sentința sa este apelabilă. 


\section{Dreptul la apel a instituțiilor ecleziastice din Transilvania}

De la jumătatea secolului al XII-lea, pontiful Alexandru al III-lea (1159-1181) reformează legislația procesului conform regulilor de procedură romane și aduce importante contribuții dreptului la apel43. Tendința hierocratică se accentuează în timpul pontificatului lui Inocențiu al III-lea (1198-1216), care justifică intervenția în afacerile temporale asumându-și rolul de Vicarius Christi44. Din această calitate, de instanță supremă de judecată, extinde dreptul de apel inclusiv instituțiilor eclesiastice aflate la periferia Christianitas, spre exemplu celor din diocezele maghiare.

Așa cum am precizat la început, în secolul al XIII-lea, intervenția Sfântului Scaun se intensifică în regatul maghiar. Cea mai vie expresie a fost implicarea acestuia din urmă în proiectele Bisericii Romane de cruciadă și creștinare ${ }^{45}$. Acestea sunt condițiile în care partea răsăriteană a regatului maghiar, Transilvania, se racordează, prima oară, în mod direct la realitățile juridico-canonice din Occident ${ }^{46}$. Ne susținem această teză prin documentele care atestă faptul că Inocențiu al III-lea oferă episcopului Transilvaniei, în decembrie 1199, dreptul de a apela la Sfântul Scaun47. Din acest moment, pe tot parcursul secolului al XIII-lea, până în 1282, nu mai puțin de patruzeci și două de documente atestă faptul că Sfântul Scaun se implică în mod repetitiv în realitățile transilvănene în urma adresărilor directe din partea instituțiilor. Aici, mai amintim o chestiune importantă: conform canoanelor epocii, Scaunul Apostolic își putea exercita direct jurisdicția asupra spațiilor în care nu există altă autoritate eclesiastică locală. În acest fel explicăm exemptarea mai multor teritorii în spațiul transilvan de-a lungul secolelor al XII-lea și al XIII-lea, asupra cărora mai târziu instituțiile eclesiastice locale sau instituțiile seculare vor fi încercat să-și exercite jurisdicția ajungându-se la abuzuri și procese prin înaintarea apelului la Curia Romană.

Înainte de a trece la analiza documentelor, trebuie să facem o precizare importantă. Documentele pe care le avem la dispoziție în acest moment sunt emise în cele mai multe cazuri de către cancelaria pontificală. Prin urmare cunoaștem doar data în care Suveranul Pontif răspunde apelului înaintat de către instituțiile eclesiastice ${ }^{48}$ (episcopie, capitlul catedral, prepozitura etc.. Presupunem că recursurile și solicitările au fost înaintate de acestea în acelaşi an sau cu un an în urmă. 
Din punct de vedere juridic, exista un set de reguli de procedură care se aplica, asemeni unui șablon, în fiecare situație în care intervenea instanța apostolică. În primul rând, o instituție ecleziastică își exprima intenția față de Scaunul Apotolic printr-o cerere oficială sau prin trimiterea reprezentanților în audiență la pontif. În cazul în care instituția în cauză apela la judecată, Sfântul Scaun răspundea prin trimiterea anchetatorilor pentru a culege informațiile necesare pentru judecată. În spațiul transilvănean, de cele mai multe ori, în poziția anchetatorului erau numiți diverşi demnitari ecleziastici neutri precum episcopul, canonicii unui capitlu sau prepozitul etc. În cele din urmă, procesul de judecată avea loc în teren sau chiar la Roma, cel mai cunoscut exemplu în acest sens fiind procesele din 1235 dintre episcopul Transilvaniei și decanul Țării Bârsei49. În toate exemplele pe care le vom analiza mai jos, vom remarca existența procedeului descris, ceea ce semnifică încadrarea spațiului ecleziastic transilvănean în normele juridice romane universale.

Prin graficul de mai jos ne-am propus să oglindim vizual realitatea prezentată în documente. După cum observăm, instituția episcopiei exercită cel mai des de dreptul de apel în nu mai puțin de 12 cazuri. Pe treapta următoare se află Ordinul Teuton și instituția capitlului, ambele utilizând recursul de cinci ori, în cele mai multe cazuri în urma conflictului cu alte instituții. Urmează prepozitura, care uzitează de acest drept de patru ori, Ordinul Benedictin de trei ori, Ordinul Dominican și Ordinul Cistercian de două ori, iar arhiepiscopia o singură dată.

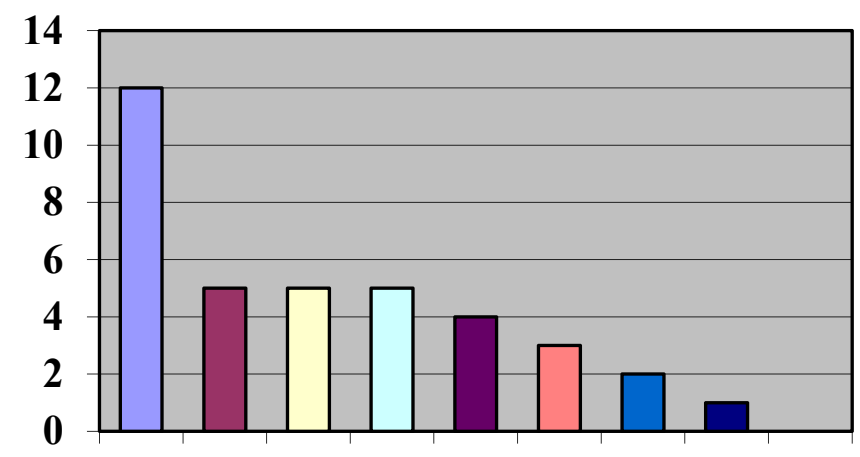

Nr. apelurilor instituțiilor eclesiastice

口Arhiepiscopia
口Ordinele mendicante
$\square$ Ordinul Benedictin
$\square$ Prepozitura
$\square$ Instituţia Capitlului
$\square$ Ordinul Teuton
$\square$ Ordinul Cistercian
$\square$ Episcopia




\section{Arhiepiscopia}

Până în acest moment avem cunoștință doar despre un singur caz în care există un apel din partea arhiepiscopului. În 3 mai $1205^{50}$, arhiepiscopul de Kalocsa apelează la Sfântul Scaun pentru a primi dreptul de a-și extinde jurisdicţia asupra unui episcopat de pe „pământul fiilor cneazului Bela” care nu este supus niciunei mitropolii şi care poate fi ortodox. Este foarte importantă posibilitatea episcopatului ortodox deoarece se observă noi raporturi între Biserica Romană şi Biserica Constantinopolitană.

Din răspunsul suveranului pontif, cuprins în documentul citat, observăm cauza apelului şi mai mult, contextul juridic existent, ce are o importanță accentuată. În 1205, unitatea Bisericii Occidentale cu cea Orientală este realizată sub umbrela Romei (prin cucerirea Constantinopolului de către cruciați în 1204), așadar nu mai este vorba de o schismă, ci doar de o recunoaștere de iure a autorității Constantinopolului asupra episcopatelor ortodoxe de la nordul Dunării și nu numai. În aceste condiții, Suveranul Pontif subliniază acest aspect în scrisoare „Totuşi să fii cu multă băgare de seamă ca acel episcopat să nu fie cumva supus Bisericii din Constantinopol întrucât această Biserică din Constantinopol s-a reîntors de curând la unitatea scaunului apostolic, nu vrem s-o lipsim de dreptul ei..." ${ }_{51}$

Pe de altă parte, dacă situația a existat în acest fel, deducem că episcopatele ortodoxe de la nordul Dunării sau cel puțin cele aflate în arcul carpatic nu se mai aflau de facto sub autoritatea Constantinopolului, chiar înainte de refacerea unității Bisericii Universale cu un an în urmă. În această idee atragem atenția că evenimentul este asemănător cu cel din 1204, când Inocențiu al III-lea a cerut episcopului de Oradea și abatelui de Petis, din dieceza Veszprem² ${ }^{2}$, să cerceteze situația comunității de monahi ortodocşi din aria lor de competență și a hotărât înființarea unui episcopat latin care să o înglobeze.

Revenind la chestiunea apelului, el este utilizat de arhiepiscop pentru confirmarea unor drepturi noi în raport cu episcopatele ortodoxe. Până în 1204 nu mai existase o unitate a Bisericilor Constantinopolitană și Romană din antichitatea târzie, prin urmare, în momentul când acesta s-a întâmplat din nou, arhiepiscopul trebuia să acționeze în consecință. 


\section{Episcopia}

Din secolul al VIII-lea, autoritatea jurisdicțională a episcopului se conturează tot mai mult în funcție de conexiunile personale şi familiale și nu mai este relaționată de fostele delimitări teritoriale ale diocezei în conformitate cu vechile provincii romane. Așadar dezvoltarea diocezei într-o entitate juridic-teritorială a fost un proces lung care s-a clarificat în secolele al XI-lea şi al XII-lea. În secolele al XII-lea și al XIII-lea, culegerile importante de drept canonic reglementează funcțiile episcopului și îi consolidează poziția sa centrală în cadrul vieții spirituale și temporale a unei dioceze delimitată teritorial. Sediile episcopale devin adevărate capitale și centre de putere, inclusiv în domeniul juridic53, ciocnindu-se de alte autorități mai noi sau mai vechi. Astfel înţelegem motivul pentru care episcopia, inclusiv în Transilvania este instituția care a uzitat cel mai mult acest drept de apel în comparație cu toate celelalte instituții ecleziastice, pentru a-și păstra autoritatea.

Într-un arc de timp cuprins între anii 1199, când episcopul Transilvaniei primește dreptul de apel şi 1277, când avem ultima mențiune a recursului episcopului, cuantificăm 12 apeluri în 78 de ani către instanța apostolică. Cu toate acestea, Sfântul Scaun intervine în mai multe cazuri în afacerile episcopiei Transilvaniei54 însă, din documentele pe care le avem, nu rezultă explicit că episcopia ar fi înaintat apelul înaintea fiecărei intervenții a Romei. Așadar fără a lua în considerare recursurile presupuse le vom enumera 55 doar pe cele explicite și le vom împărți în patru categorii: 8.1) încălcarea jurisdicției asupra proprietăților și bunurilor: patru apeluri; 8.2) exercitarea autorității asupra Țării Bârsei: două apeluri; 8.3) chestiuni administrative ${ }^{56}$ : patru apeluri; 8.4) chestiuni spirituale57: un singur apel. Le vom analiza doar pe cele mai importante

\section{1 Încălcarea jurisdicției asupra proprietăților și bunurilor}

Numărul apelurilor din această categorie însumează aproximativ 40\%. În acest sens există 5 apeluri: în 1220 episcopul Cenadului a apelat la instanța apostolică având în vedere că a fost păgubit de către episcopul din Oradea. Suveranul Pontif a hotărât ca acesta din urmă să-l despăgubească pe 
episcopul de Cenad pentru pagubele aduse. Așadar i-a numit pe priorul de Igriș și pe prepozitul de Arad să impună această sentință definitivă, fără a-i permite episcopului de Oradea un nou apel.

În 1223 este emis, la Lateran, un document ${ }^{58}$ prin care Suveranul Pontif amintește că un anumit Grigore, fiul lui Calad a produs pagube prepozitului din Arad, în consecință (în urma unui proces despre care nu avem nicio informație) a fost afurisit. În continuare, documentul ne spune faptul că Grigore a înaintat un apel către Scaunul Apostolic pentru ridicarea pedepsei. În urma acestuia, o nouă sentință a fost emisă, anume obligația lui Grigore de a-l despăgubi pe prepozit, iar în acest sens pontiful îi însărcinează, prin documentul citat, pe arhiepiscopul de Esztergom și abatele de Igriș să se asigure de acest fapt. Documentul nu ne prezintă identitatea respectivului Grigore. Deoarece pontiful l-a numit pe arhiepiscopul de Esztergom (cel mai înalt ierarh al Bisericii maghiare) să supravegheze cazul, presupunem că Grigore ar fi fost episcop.

Apoi între 1232 și 1235, episcopul Transilvaniei, Rainald, a înaintat nu mai puțin de trei apeluri în vederea soluționării conflictului cu abatele conventului dominican din Cluj59. Remarcăm, din nou, o suprapunere a jurisdicţiilor celor 2 instituții. Sfântul Scaun răspunde prin trimiterea unor judecători delegați, care să cerceteze cazul și să emită o sentință. Cu toate acestea, observăm că sentințele se amână din cauza faptului că unul dintre litiganți lipsește la proces, fiind ulterior pedepsit.

În urma acestor cazuri observăm că procesele pot să se întindă pe o perioadă de timp îndelungată datorită regulilor de procedură ce impun amânarea sentinței din diferite motive. În continuare, vom vedea că se impune sentința definitivă, în special pentru a micșora perioada proceselor.

\subsection{Exercitarea autorității asupra Țării Bârsei}

Următoarele apeluri, ale epicopului Rainald, în 1235, au în vedere exercitarea jurisdicției asupra Țării Bârsei, un teritoriu în care, în ochii Curiei Romane, ierarhia eclesiatică se afla în afara celei maghiare. Dat fiind faptul că materialul juridico-istoric privind procesele dintre Ordinul Teuton, pe de o parte, și instituțiile ecleziastice sau laice, pe de altă parte, se limitează la un 
număr mic de documente, noi precizăm că procesul din 1235, dintre episcopul Transilvaniei și decanul Țării Bârsei, rămâne cel mai amplu documentat. El reflectă în modul cel mai limpede felul în care un proces se desfășoară în 3 etape la curia pontificală ${ }^{60}$.

\subsection{Aspecte administrative}

În această categorie avem trei apeluri: în 1219, 1255 și în 1277. În 1219 episcopul cere aprobarea Sfântului Scaun de a interveni în afacerile interne ale mănăstirii benedictine din Itebea, pentru a o sprijini din punct de vedere material și financiar. Episcopul recunoaște aşadar privilegiul de exempțiune de care se bucură Ordinul Benedictin. Datorită faptului că mănăstirea se află sub jurisdicţia directă a Romei, Suveranul Pontif trimite, ca răspuns, doi delegaţi pentru cercetarea situaţiei şi administrarea ulterioară a acesteia.

În 1255, pontiful trimite o scrisoare episcopului Transilvaniei răspunzând apelului său. Acesta ceruse aprobarea Sfântului Scaun de a mări veniturile bisericii catedrale din Alba Iulia pentru a plăti prebendele canonicilor care refuză să îndeplinească serviciile liturgice. Ceea ce ne suscită atenția este faptul că pontiful condiționează mărirea prebendelor oferite de susținerea serviciilor şi interzice dreptul la apel tuturor celor ce se opun acestei decizii. Cunoaștem faptul că legislația canonică a apelului este încă permisivă în multe privințe însă aici observăm cum intervin amendări, pas cu pas, pontiful impunând restricții. Astfel de canoane, privind interzicerea apelului în situații particulare, se înmulțesc fiind incluse, în cele din urmă, în corpusurile de drept. În plus, în peisajul instituțional transilvănean, documentul arată implicarea activă a Scaunului Apostolic în chestiunile interne ale episcopiei, un fapt repetitiv în veacul al XIII-lea, ce reflectă atmosfera hierocratică a secolului.

Ultimul document, din 1277, reprezintă cererea adresată de pontif episcopului de Oradea de a-l aduce pe Nicolae, prepozitul Transilvaniei și arhiepiscop de Esztergom, în fața instanței apostolice, în vederea judecării unui proces privind legalitatea alegerii sale ca arhiepiscop. Procesul a început la o dată precedentă nemenționată, când Benedict, canonic al bisericii din Esztergom, susținea că a fost ales arhiepiscop legitim, în contrast cu Nicolae. Pe noi ne interesează faptul că Benedict înaintase apelul către Sfântul Scaun. 
În consecință pontiful Inocențiu al V-lea începuse ancheta, care nu s-a sfârșit însă în timpul pontificatului său. Presupunem că motivul dublei alegeri în funcția de arhiepiscop (a lui Benedict și a lui Nicolae) și a procesului ce decurge de aici reprezintă o confuzie în materie de drept canonic, așa cum vom mai vedea în alte situații.

În încheiere, amintim că instituția episcopiei apelează la Sfântul Scaun de două ori, din varii motive. Remarcăm că cele predominante se referă la chestiunile administrative și cele legate de conflictul cu alte instituții.

In graficul de mai jos am reflectat proporția cazurilor în care episcopia a apelat către Sfântul Scaun.

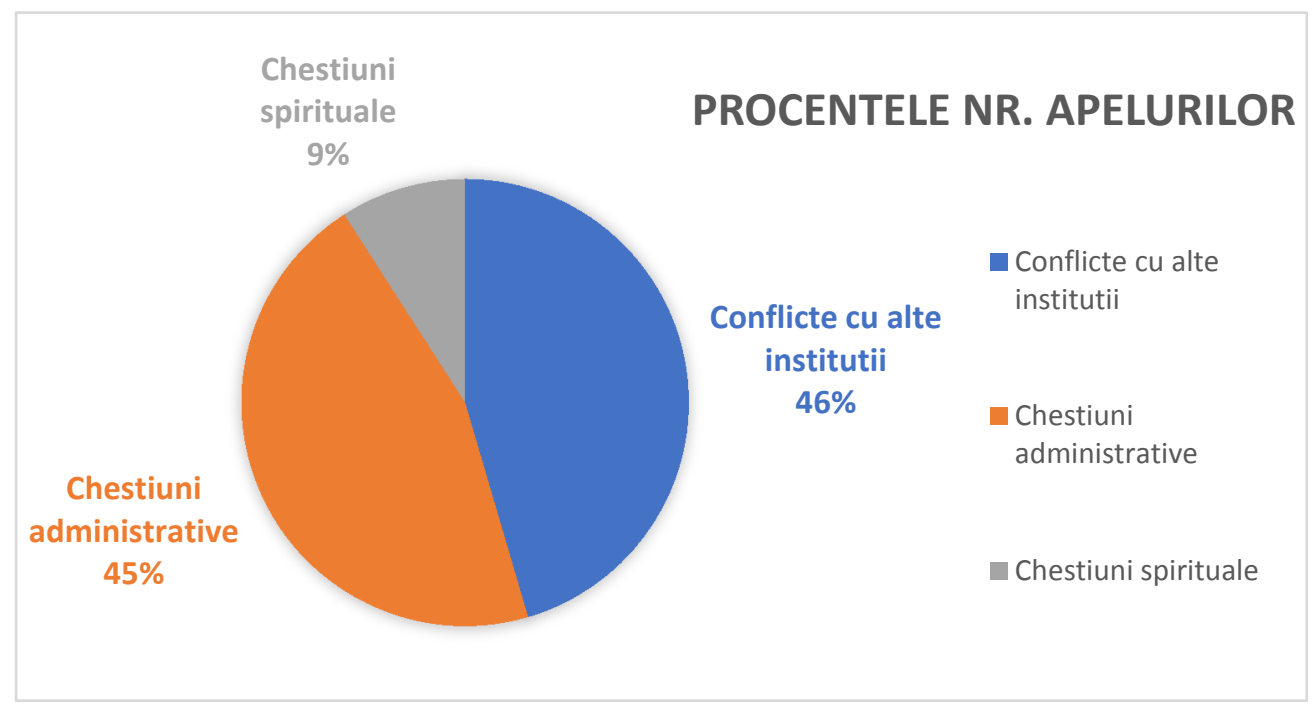

\section{Instituția capitlului}

În secolele al XI-lea și al XII-lea, instituția capitlului ${ }^{61}$ se comportă asemeni unei corporații medievale, reprezentantă a vocii clerului unei dioceze, având atribuții electorale, culturale etc. În secolul al XII-lea, ea este definită în principalele culegeri de drept în acești parametri, evidențiindu-se dreptul de a participa la conciliile provinciale și la cele convocate de Suveranul Pontif62.

\section{5}


Totuși, de la jumătatea secolului al XIII-lea, aspirațiile hierocratice impun o intervenție frecventă a Sfântului Scaun în afacerile capitlului ${ }^{63}$. În aceste condiții au loc evenimentele prezentate în cele ce urmează.

Intervențiile Suveranului Pontif ca urmare a apelurilor înaintate de către capitluri se întind pe o perioadă de 56 de ani, între 1226 și $1282^{64}$. În urma unui inventar, privind implicarea Sfântului Scaun în afacerile capitlurilor din Transilvania, putem să clasificăm cauzele acesteia în trei categorii: 9.1) Apelul pentru un proces în vederea soluționării unui conflict; 9.2) Apelul în vederea confirmării privilegiilor; 9.3) Apelul în vederea confirmării drepturilor.

\subsection{Apehul pentru soluționarea unui conflict cu alte instituții}

În această categorie includem un singur caz, anume în decembrie 1232 când capitlul din Oradea apelează la Sfântul Scaun pentru rezolvarea conflictului cu abatele Benedict, lector excomunicat din Strigoniu.

Cazul $^{65}$ a fost prezentat în fața Curții Apostolice de către doi canonici ce reprezentau capitlul din Oradea. Conform explicațiilor pontifului către legații judecători (numiți Iudex Delegatus), s-a dezvoltat un conflict între o facțiune majoritară a canonicilor și o facțiune minoritară. Facțiunea majoritară a ales un magistru numit Primogenitus, ce a intrat în conflict cu abatele Benedict, alesul facțiunii minoritare. Nerecunoscând autoritatea celuilalt, ambii opozanți au uzitat de dreptul la apel, aşadar au avut loc două procese fără un rezultat satisfăcător ${ }^{66}$, până în momentul în care legatul apostolic a emis o sentință definitivă. Așadar procesul s-a încheiat în urma faptului că legislația canonică a permis doar emiterea unei sentințe inapelabile ${ }^{67}$.

\subsection{Apelul înaintat de capitlul din Cenad în vederea confïr- mării privilegiilor, veniturilor}

În această situație, episcopul și capitlul din Cenad apelează în 1226 la Scaunul Apostolic pentru a primi dreptul de a mări veniturile canonicilor sau de a schimba felul în care le administrează, în urma dezastrului financiar cauzat de războaie și jafuri68. Documentul subliniază că lipsa veniturilor pentru plata prebendelor (salariilor) canonicilor din capitlu i-a determinat 
pe aceștia să renunțe la serviciul liturgic. Chiar dacă documentul nu ne oferă multe informații despre apelul în sine, el este similar cu cel înaintat de episcopul Transilvaniei în 1255 pentru a mări veniturile bisericii catedrale in Alba Iulia. Observăm astfel că, în secolul al XIII-lea, episcopiile şi capitlurile, dar şi mănăstirile sau conventele, se confruntau cu numeroase probleme financiare.

În situația de față, Suveranul Pontif răspunde apelului prin trimiterea unui delegat care să cerceteze cazul și să emită o sentință.

\subsection{Apelul în vederea confirmării drepturilor}

Ultimul document din acest secol, care ne sugerează înaintarea apelului către Roma din partea capitlurilor, este emis în jurul anului $1282{ }^{69}$ şi ne reamintește de ecourile Sinodului General de la Buda din $1279^{70}$. Din răspunsul pontifului știm următoarele: capitlul bisericii din Oradea a ales în funcția de episcop un demnitar pe nume Toma, care conform dreptului canonic trebuia confirmat de arhiepiscopul de Esztergom. Totuși, legatul Filip de Fermo a anulat această confirmare, motivând că Toma nu mai activase într-o funcție eclesiastică de peste un an, prin urmare, conform canoanelor stabilite la Conciliul Lyon II (1274), el nu mai avea dreptul de a fi numit episcop. În aceste condiții, dacă alegerea lui Toma era invalidă, scaunul episcopal rămânea vacant, motiv pentru care canonicii din capitlu au înaintat apelul către Roma. Așadar Suveranul Pontif l-a numit pe arhiepiscop să cerceteze situația, pentru a verifica dacă alegerea a fost legală și în consecință să-l numească episcop.

Aici menționăm că documentul ne arată o chestiune foarte importantă: Suveranul Pontif corectează o interpretare greșită a dreptului canonic din partea lui Filip de Fermo privind alegerea episcopilor. Conform Conciliului Lyon II măsurile descrise mai sus se aplicau doar demnitarilor ce ocupau funcții în biserici parohiale, nu în cele ale capitlurilor cum era cea din Oradea. Prin urmare, numirea lui Toma ca episcop devenea validă. Presupunem că în capitlu se aflau canonici ce aveau cunoștințe despre aceste detalii juridice, deoarece au acționat în cunoștință de cauză împotriva deciziei legatului. De asemenea, la fel ca în documentul precedent, acesta ne demonstrează intervenția Scaunului Apostolic în afacerile interne ale capitlului.

\section{7}




\section{Ordinul Teuton}

În 1211 o facțiune a Ordinului Teuton a fost cantonată în Țara Bârsei, în cadrul proiectului de cruciadă susținut de Biserica Romană împotriva ereticilor şi păgânilor din Orient. Timp de 14 ani monahii cavaleri teutoni din Țara Bârsei se bucură de donații oferite de regele maghiar și de privilegii din partea Sfântul Scaun, printre care amintim privilegiul exempțiunii (Țara Bârsei a intrat în Proprietatea Sfântului Petru, adică sub autoritatea directă a Scaunului Apostolic).

În schimb, în 1225 regele maghiar i-a alungat pe teutoni din aceste teritorii, iar episcopul Transilvaniei și-a arogat autoritatea canonică asupra Țării Bârsei, care se afla în fapt sub autoritatea Romei. După cum observăm, din lista apelurilor ${ }^{71}$, doar cel din 1223 privește o chestiune administrativă internă, respectiv numirea într-o functie ecleziastică. În rest, din 1225, Ordinul Teuton apelează în repetate rânduri către Scaunul Apostolic, timp de 10 ani, în vederea soluționării problemei cu regalitatea maghiară și cu episcopul Transilvaniei. Ecourile apelurilor nu întârzie, având în vedere că Scaunul Apostolic intervine de cinci ori, în mod concret, prin ancheta episcopului cuman din 1235.

\section{Ordinul Cistercian}

În mod natural instituțiile monahale nu vor refuza apelul din moment ce acesta reprezenta un mecanism eficient in fata intervenției episcopatului sau monarhiei în afacerile lor interne. Ne referim aici la cazurile în care episcopul sau monarhul le încălcau jurisdicția asupra propriilor teritorii. Pe de altă parte, abuzul de acest instrument, deosebit de eficace, oferea adeseori posibilitatea de a deteriora ordinea internă a ordinului cistercian. În contextul în care monahii primesc dreptul de a apela împotriva unei decizii emise de abatele lor, papa intervine peste sentința abatelui și poate destabiliza ierarhia internă a ordinului, ce se conturează ca o lume închisă.

Așadar limitele dreptului de apel sunt evidențiate pentru a inhiba abuzurile specifice care vor privi aspecte interne ale vieții religioase, atât a unei singure comunități, cât și a unui ordin monahal ${ }^{22}$. Reținem aici cuvintele 
lui Bernard de Clairvaux, privit ca o autoritate în chestiunea ordinelor monahale, ce avertiza, într-o scrisoare adresată pontifului Inocențiu al II-lea, că dacă acest drept de apel nu era uzitat din motivul unei carențe în justiție, atunci era nejustificat 73 .

În regatul maghiar abația cisterciană mamă de la Pontigny a fondat trei mănăstiri, în cadrul unei ample mișcări misionare în Orient. În est, în Transilvania ne referim la două mănăstiri: la Igriș și Cârța.

După cunoștințele noastre, există doar două cazuri în care abatele mănăstirii cisterciene Igriș apelează la Sfântul Scaun. Prima oară este în jurul anului $1224^{74}$, când solicită întărirea unui schimb de moşii și alte bunuri cu regele maghiar. A doua dată este în 1236, când monahii mănăstirii Igriș și magistrul Fraților Ospitalieri din Ierusalim a Cavalerilor Templieri apelează la Sfântul Scaun pentru a interveni pe lângă regele maghiar, Bela al IV-lea, care nu le-a respectat privilegiile oferite de predecesorii săi 75 . Nu cunoaștem rezultatul procesului însă observăm imaginea de ansamblu. Acest comportament al monahilor cistercieni se încadrează în șablonul cunoscut, asemeni prepoziturii, ce a uzitat de instrumentul apelului când s-a simțit agresată.

\section{Ordinul Benedictin}

Istoricul Kiss Gergely ne sugerează că cea mai mare parte a mănăstirilor benedictine din regatul maghiar suferă schimbări în privința raportului juridic cu Sfântul Scaun, într-o perioadă cuprinsă între sfârşitul secolului al XII-lea şi jumătatea secolului al XIII-lea. Dacă în secolul al XII-lea, putem afirma exercitarea jurisdicției episcopului diocezan asupra lor, de la începutul secolului al XIII-lea, odată cu pontificatul lui Inocențiu al III-lea, ele intră tot mai mult sub o subordonare directă față Sfântul Scaun ${ }^{76}$. O asemenea tendință se observă și în cazul mănăstirilor din Transilvania, prin urmare în această atmosferă hierocratică plasăm apelul lor către Roma.

Din informațiile pe care le avem până acum, cunoaștem trei cazuri de apel înaintate de către două mănăstiri benedictine transilvane, cea de la Bistra, în 1235 și 1236, respectiv cea de la Almaș din 1239. În aceste situaţii atât mănăstirea din Bistra, cât și cea din Almaș, înaintează apelul pentru a se proteja de actele considerate agresive din partea episcopului de Cenad, respectiv de comitele Transilvaniei. 
Un prim caz77 are loc în jurul anului 1235, când abatele mănăstirii din Bistra apelează la Roma pentru a fi despăgubit în urma conflictului cu episcopul de Cenad, iar Sfântul Scaun declanșează ancheta pe data de 9 iulie prin trimiterea în teritoriu a abaților de la biserica Sf.Martin din Panonia şi Sf. Salvator din Szekszard. Nu ştim rezultatul procesului însă documentul ne spune că acesta este al doilea de acest fel (și al doilea apel), având în vedere că problema nu se rezolvase după prima sentință. Ne gândim, precum în cazul capitlului Oradei, și de această dată, al doilea apel este ultimul permis, sentința fiind definitivă.

De asemenea, într-un document trimis abaților de Oradea, de Tihon şi de Erte în $1236^{78}$, pontiful Grigore al IX-lea precizează că abatele de Bistra înaintase un apel către Sfântul Scaun, într-o dată neprecizată, aflându-se în conflict cu episcopul de Cenad care dorea să îți exercite jurisdicţia asupa mînăstirii în cauză. Pontiful îl numise pe legatul Iacob de Preneste judecător, care a emis o sentință definitivă stabilind faptul că mănăstirea se află în afara jurisdicţiei episcopiei. Totuși, episcopul de Cenad, nemulțumit, aflându-se în imposibilitatea apelului, a jefuit mănăstirea Bistra și l-a omorât pe abate. În documentul de față, pontiful îi însărcinează pe abații sus numiți să cerceteze crima însă nu ştim explicit dacă răspunsul pontifului este rezultatul unui apel ulterior.

A doua situație pe care o avem în vedere are loc în 1239, când Scaunul Apostolic intervine direct, ca urmare a apelului înaintat de mănăstirea benedictină de la Almaș, pentru a lua măsuri împotriva abuzurilor ce i s-au făcut mănăstirii de către Ladislau 79 , comitele diecezei Transilvaniei. În acest caz, pontiful Grigore al IX-lea, îi trimite ca anchetatori pe abatele de Cubis, pe abatele de la biserica Sf. Ioan, din diecezele de Oradea și Transilvania, și pe prepozitul de Oradea, cărora le transmite, ca în urma cercetărilor, să stabilească o dată a procesului în care să se prezinte ambele părți ce vor fi judecate, cel mai probabil la Roma ${ }^{80}$.

\section{Ordinul Mendicant Dominican}

Aici aminitim că teritoriile conventelor dominicane devin exempte, ceea ce înseamnă că se situează în afara exercițiului juridic al instituțiilor eclesiastice sau seculare locale, aflându-se sub jurisdicția Scaunului Apostolic. 
Până acum am identificat un singur apel din partea mendicanților. În jurul anului 1222 conventul dominican al Fericitei Maria din Cluj apelează la Sfântul Scaun pentru a le înnoi privilegiul dat și pentru a li se face dreptate „în urma neajunsurilor ce li s-au adus" ${ }^{81}$ din partea episcopului Adrian. Pe scurt, din scrisoarea pontifului emisă în 21 iunie 1222 către anchetatori, episcopul de Vac, abatele mănăstirii Igriș și prepozitul de Vac, aflăm că episcopul Adrian a adus numeroase pagube materiale conventului dominican şi a ars documentele care menționau privilegiile de care acesta se bucura, printre care amintim și privilegiul exempțiunii. Nu cunoaștem rezultatele procesului însă remarcăm același șablon, ca în cazul celorlalte instituții ecleziastice

\section{Instituția prepoziturii}

Privind lista ${ }^{82}$ situațiilor în care această instituție a înaintat apelul, remarcăm o serie de motive care stau la baza sa: soluționarea conflictului cu instituția regală în 1223 sau anularea sentinței excomunicării în 1235. Cele mai multe însă privesc chestiunile administrative: confirmarea unei înțelegeri cu subdiaconul Ioan Capucius în 1227, aprobarea unui candidat în funcția de episcop în 1245 și, în ultimul rând, în 1247, confirmarea dreptului de a muta sediul episcopal. Dintre toate acestea, ne vom opri să analizăm două cazuri mai importante: cel din 1223 și 1235 .

În 1223 avem un document ce exprimă un conflict între regalitate şi prepozitura Aradului. Documentul conține o poruncă adresată de Suveranul Pontif arhiepiscopului de Strigoniu, episcopului de Vesprim și abatelui de Igriș de a cerceta cazul și a hotărî o sentință, eventual a pune presiuni asupra regelui pentru a-l determina să aducă despăgubiri prepozitului și capitlului bisericii din Arad în urma unor pagube aduse. Prepozitul înaintase apelul către o instanță superioară în urma unor agresiuni, prin urmare cazul este asemănător cu cel al capitlurilor sau mănăstirilor, care au intrat în conflict cu monarhia, ce dorea să-şi extindă autoritatea asupra lor

Următorul caz are în vedere conflictul dintre prepozitul de Arad și arhiepiscopul de Esztergom. În urma faptului că arhiepiscopul l-a excomunicat pe prepozit, acesta din urmă a înaintat apelul către instanța apostolică cerând revocarea sentinței de excomunicare. Conform regulilor de procedură, Suveranul 
Pontif declanşează o anchetă însărcinându-i pe abatele de Pilis, de Bellafons şi pe arhidiaconul din Bach, să cerceteze cazul și să trimită la Roma rezultatele anchetei în vederea desfășurării judecății. Nu cunoaștem rezultatul procesului însă dorim să subliniem încă o dată că sentința de excomunicare în sec. al XIII-lea este apelabilă, la fel cum ne amintește procesul canonicilor capitlului din Oradea din 1232.

\section{Cuvinte de încheiere}

Fenomenul juridic care se prezintă atât de viu în peisajul transilvănean din secolul al XIII-lea este rezultatul unui lung proces evolutiv care nu poate fi observat decât printr-o distanțare de fenomenele particulare și o apropiere față de imaginea de ansamblu.

Documentele ne transmit faptul că toate instituțiile ecleziastice, ce joacă un rol propriu și important pe scena de teatru a Evului Mediu, uzează de dreptul la apel. Cu toate că unele instituții îl folosesc mai puțin, altele mai mult, într-o singură concluzie afirmăm că toate îl asumă ca un drept cuvenit şi o realitate normală. Conflictele ivite între ele, sau în interiorul lor, își găsesc rezolvarea prin apelul la Curtea Pontificală care se afirmă ca instanță supremă de judecată, o expresie vie a epocii hierocratice.

Peisajul juridic transilvănean devine multicolor în secolul al XIII-lea însă se încadrează perfect în panorama generală regatului maghiar și, la rândul său, în cea a Europei unde jurisdicțiile se suprapun unele peste altele. Suprapunerea jurisdicțiilor și a autorităților diverselor instituții creează conflicte, dar acestea încep să se rezolve, din secolul al XIII-lea, în tribunalele eclesiastice, pe baza unor legi scrise şi clare. În acest peisaj se impune un sistem juridic universal și unic bazat deopotrivă pe morala creștină și pe principiile raționale ale dreptului roman.

În acest cadru va fi uzitat dreptul de apel către Sfântul Scaun. Preluat din dreptul roman, metabolizarea sa denotă o maturizare a gândirii juridice medievale pentru că accentuează, și mai puternic, nuanța de raționalitate și echitate a judecății care devine un principiu universal, în mod sigur din 1235, odată cu publicarea corpusului de canoane Liber Extravagantium. Fenomenul este un rezultat extraordinar al minții creștine deoarece el poate să existe doar într-o societate creștină a cărei dispozitiv mental este bazat pe echilibrul între rațiune și credință, respectiv între ius civilis și ius canonicum. 
Dreptul la apel a continuat să fie utilizat în procese şi după apusul Evului Mediu (secolele al XIV-lea și al XV-lea). Însă faptul că el a fost utilizat în Transilvania medievală, alături de celelalte regate din Occident, ne arată că apelul, încadrat în tot ansamblul dreptului roman, face parte dintr-un strat cultural comun europenilor.

\footnotetext{
* Absolvent al Facultatii de Istorie si Fïlosofie, Master: „Societate, artă, identități în Europa Centrală. De la medieval la modernitate”, Universitatea Babes-Bolyai. Contact: tudor.steff@gmail.com.

${ }^{1}$ Recomandăm vocea consacrată a istoricului Charles Hormer Haskins oglindită în lucrarea, The Renaissance of the Twelfth Century, Harvard University Press, 1955.

${ }^{2}$ Referitor la mișcările economice și demografice din secolele al XI-lea şi al XII-lea, a căror ecou se observă în plan cultural prin dezvoltarea dreptului scris, recomandăm lucrarea lui Peter Landau, The Development of Law, în Cambridge History of Medieval Europe, vol.II ed. Cambridge University Press, 2008.
}

3 Recomandăm lucrarea clasică a lui Gabriel le Bras, Storia della Chiesa. Le istituzioni ecclesiastiche della cristianita medievale, ediția italiană coordonată de P.Ciprotti, L.Prosdocimi, A.Giacobbi e G.Pelliccia, Editrice S.A.L.E - Torino, 1973 și Paolo Grossi, L `ordine giuridico medievale, ed. Laterza, Roma, 1995.

4 Pentru detalii privind felul în care principiul echilibrului teologico-politic (între autoritatea spirituală şi cea temporală), lansat de Papa Gelasius I, determină materializarea principiului juridic utrumque ius, în secolul al XII-lea, recomandăm lucrarile lui Ennio Cortese, Il diritto nella storia medievale. Il baso medioevo, Il Cigno Galileo Galilei Edizioni di Arte e Scienza, Roma, 1995, pp. 229-235 și Francesco Calassi, Medioevo del diritto. Parte seconda: Il sistema del diritto comune (sec.XII-XIV) ed. Dott.A.Giuffre, Milano, 1954, pp. 392-407.

5 Pentru o imagine generală asupra istoriei Bisericii Romane, între secolele al XI-lea și al XIVlea, inclusiv a epocii teocratice, recomandăm lucrările lui Walter Ullmann, The Growth of Papal Government In The Middle Age, Methuen and Co.LTD London Press, 1962 și Agostino Paravicini Bagliani, Il trono di Pietro.L ‘universalita del papato da Alessandro III a Bonifacio VIII ed.Carocci, Roma, 2001.

${ }^{6}$ Pentru detalii privind compunerea colecțiilor de canoane recomandăm lucrarea cardinalului Péter Erdő Storia Della Scienza Del Diritto Canonico. Una introduzione, Editrice Pontificia Universita Gregoriana, Roma,1999 pp. 37-78 și, de asemenea, articolul lui Charles Duggan Decretal Collections from Gratian `s Decretum to the Compilationes antiquae: The Making of New Case Law publicat în volumul colectiv The History of Medieval Canon Law in the Classical Period 114O-1234. From Gratian to the Decretals of Pope Gregory IX, ed. The Catholic University of America Press, Washington D.C. 2008.

7 Pentru fenomenul cultural de asimilare a dreptului roman în organismul Bisericii, recomandăm lucrarea lui Kenneth Pennington The «Big Bang»: Roman Law in the Early Twelfth-Century, articol publicat în «Rivista internazionale di diritto commune», 18/2007, pp. 43-70 și Idem, Roman Law at the Papal Curia in the Early Twelfth Century, articol publicat în volumul colectiv Canon Law, Religion, and Politics: Liber Amicorum, ed. The Catholic University Press of America, 2012, pp. 233-252. 
${ }^{8}$ Dreptul roman a cunoscut o revigorare atât de limpede în spațiul italian și datorită faptului că aici s-au prezervat mai consistent anumite structuri ierarhice administrative din perioada imperiului, spre exemplu ierarhia eclesiastică. Din acest motiv, glosatorii au conservat ierarhia originală a apelului.

9 În istoriografie sunt numiți glosatori juriștii care au început studiul manuscriselor Codului lui Iustinian prin adnotarea comentariilor proprii, numite glose pe marginea textului. Cea mai renumită Școală a juriștilor glosatori este cea întemeiată de Irnerius în 1095 la Bologna. Patru succesori ai acestuia s-au remarcat prin studiile lor și au fost numiți Quator Doctores: Bulgarus, Martinus Gosia, Jakobus şi Hugo. Pentru mai multe detalii despre prima şcoala boloneză de drept roman, recomandăm lucrarea lui Vinogradoff Paul, Roman Law in Medieval Europe, ed. Harper and Brothers, London and New York, 1909 și Verger Jacques Culture, enseignement et societe en occident aux XII et XIII siecles, ed. Presses Universitaires de Rennes, 1999.

10 Împăratul Iustinian a avut inițiativa unei reforme legislative, pentru a înlocui Codul de legi emis de împăratul Theodosius în 438. În 528, el a numit prima comisie de juriști, care a început redactarea unui nou cod de legi, care să elimine contradicţiile existente și să includă cele mai noi norme. Această lucrare numită Novus Codex Iustinianus a fost emisă în 529. În 530 a fost numită o nouă comisie, condusă de Tribonianus, care a creat un nou corpus ce cuprindea Novus Codex și inclusiv norme mai vechi din secolul III. În noiembrie 534 a fost emis corpusul ce cuprindea Institutes, manual pentru studiu în universități, Digeste_un compendiu reunind 50 de cărți și tratate de drept aparținând celor mai importanți juriști din perioada Republicii și Imperiului_şi Codex - un compendiu al constituțiilor imperiale, A se vedea: Charles Radding, The Corpus Iuris Civilis in the Middle Age, Ed. Brill, LeidenBoston, 2007, p. 20.

${ }^{11}$ Antonio Paddoa Schioppa, Ricerche sull `appello nell diritto intermedio, ed.Giuffre, Milano, 1970 p. 21.

12 „Appello nei giudizi ordinari, appello nelle pronunce degli arbitri: il ricorso succesivo alla sentenza e dunque ormai una possibilita concreta, incardinata in tutto l'ordinamento giudiziario, un evento naturale contro il quale non sono piu fissate sanzioni di sorta; anzi, l'aplicazione del rimedio doveva risultare tanto piu estesa ed operante, in quanto i compiti del giudice erano, nel pensiero dell 'autore, particolarmente elevati e impegnativi (e percio facilmente soggetti al erorre, o comnque al reclamo). Obbietivo del giudice doveva essere infatti il raggiungimento della giustizia e della verita..." Ibidem, p. 50.

13 Irnerius (cunoscut ca Warnerius) a trait între 1050-1125. S-a afirmat ca jurist prin comentariile ample asupra Codului de Drept a împăratului Iustinian. La sfârșitul secolului al XI-lea începe să predea drept roman la Bologna. Discipolii săi Bulgarus, Martinus, Piacentinus continuă munca sa comentând și predând dreptul roman în secolul al XII-lea. Pentru mai multe detalii, despre activitatea lor, recomandăm lucrarea lui Hermann Kantorowicz Studies In The Glossators Of The Roman Law, Cambridge University Presss, 1938.

14 Termenul de hierocrație provine din doi termeni greacești: hieros, cu sensul de „sfânt”, „sacru” și cratos cu cel de „putere”. Așadar hierocrație înseamnă putere sacră. Puterea sacră era apanajul Suveranului Pontif, în special în secolul al XIII-lea, de la pontificatul lui Inocențiu al III-lea (1198-1216) la cel a lui Bonifaciu al VIII-lea (1294-1303). A se vedea Agostino Paravicini-Bagliani, op.cit. pp. 165-174. 
15 De-a lungul secolului IV, constituțiile imperiale menționează libertatea apelului, cu excepția anumitor restricții. Spre exemplu o constituție a împăratului Valentinianus din 365 amendează blocarea apelului, acesta fiind neglijat de judecătorii locali împotriva propriilor sentințe. În textul original istoricii au identificat expresia „adversus autoritatem legis appellationes neglecxerit” (apelurile sunt neglijate împotriva autorității legilor). A se vedea: Peregami Federico, Studi di diritto romano tardoantico, ed. G.Giapichelli, Torino, Milano, 2011, p. 138. De asemenea, amintim de o procedură diversă, excepțională, utilizată în cazul acestor blocaje ale apelurilor numită supplicatio. Ea specifică posibilitatea unor apeluri subsidiare, înaintate direct instanței imperiale, în cazurile în care acestea ar fi fost împiedicate de primul judecător. A se vedea, Jean Gaudemet, Institutions de l'Antiquite, Ed.Sirey, Paris, deuxieme edition, 1982, p. 803.

${ }^{16}$ Consolidarea puterii judecătorești supreme, a împăratului din Orient, este explicată de faptul că el este considerat reprezentatul lui Dumnezeu pe Pământ, conform teocrației bizantine. A se vedea, Lucio de Giovanni, Introduzione allo studio dell diritto romano tardo antico, Jovene Editore Napoli, 1999, pp. 212-214.

${ }^{17}$ Judecătorii locali, de obicei, solicitau explicații juridice judecătorilor superiori, la nivel de provincie, dar inclusiv împăratului. Dreptul de consultatio este reiterat în numerose rânduri în constituțiile imperiale. A se vedea lucrarea lui Ricardo Orestano, L 'Appello civile in diritto romano, G. Giacapichelli Editore, Torino, 1966, p. 70.

${ }^{18}$ Sentința imperială este definitivă deoarece este emisă de autoritatea supremă. Conceptul de inapelabilitate a sentinței imperiale se află la baza dreptului roman clasic, în mod particular îl surprindem în scrierile lui Ulpianus. Antonio Padoa Schioppa, Ricerche sul 'appello..., p. 93.

${ }^{19}$ La jumătatea secolului al IV-lea, apelul la episcopul Romei era un mijloc de a respinge condamnările conciliilor în diverse situații. În cazul de față, Papa Iulius I a validat apelul înaintat de episcopul Athanasie, după ce acesta din urmă fusese depus de conciliul arian din Tyr în 335. Astfel un alt conciliu arian din Antiohia din 341 a contestat posibilitatea apelului împotriva sentințelor unui sinod provincial (cu referire la ce din Tyr) fără acordul său. Cu toate acestea, în sinodul de la Sardica, din 342, s-a proclamat posibilitatea episcopului Romei (a papei) de a emite o sentință superioară deciziilor conciliare provinciale în virtutea onorării și respectării memoriei Apostolului Pentru, primul episcop al creștinilor din Roma. A se vedea: Jean Gaudemet, Eglise et Cite. Histoire du droit canonique, Ed. Cerf/Montchrestien, Paris, 1994, p. 135 .

${ }^{20}$ Canoanele 3,4,5 ale sinodului de la Sardica afirmau:

Canonul 3. „Iulius al Romei este singurul care poate decide dacă judecata împotriva unui episcop poate sau nu poate fi apelată și el este singurul numit a primi apelul sau a numi o persoană care să o facă.”

Canonul 4. „când un prelat depus apelează la curtea pontificală, scaunul său nu trebuie să fie considerat vacant înainte ca episcopul Romei să ia decizia.”

Canonul 5 „dacă Pontiful Roman poate cere episcopilor să examineze cazul unui apelant dintr-o provincie vecină, prin aceasta el este liber să le reexamineze apoi, personal sau printr-o delegație, judecata lor, dacă prelatul condamnat apelează încă o dată.” Dominic Moreau, The Papal Appeal court in sixth century: the example of roman synod of 531, articol publicat în volumul Recht Haben Recht Bekommen im Imperium Romanum, Warschau 2014 p. 372.

${ }^{21}$ Ibidem, p. 374. 
22 Într-o scrisoare din partea sinodului roman din 378 către împărat se utilizează expresia Scaunul Apostolic: "(...) dacă Damasius este egal episcopilor prin funcția sa, el se ridică deasupra lor prin prerogativele Scaunului Apostolic”. Jean Gaudemet, op.cit.p. 134.

23 Pentru înțelegerea detaliată a apelului către Roma, în prima jumătate a secolului al V-lea ne stau la dispoziție două izvoare prețioase, anume două scrisori ale Sfântului Augustin către Fabiola. În aceste scrisori oratorul și episcopul din Hippona descrie, în detaliu, două procese ale episcopului Antoninus din Fussale, Numidia, la care a luat parte. Pe scurt, episcopul Antoninus este condamnat de către sinodul provincial din Numidia la o suspendare temporară din funcție în urma abuzurilor și jafurilor întreprinse asupra populației din dioecza sa. În schimb, Antoninus înaintează un apel către Scaunul Apostolic, iar Papa Bonifaciu I răspunde trimițând o legație de episcopi care să supravegheze procesul și să emită o sentință definitivă. În urma a trei anchete privind infracțiunile episcopului, legații au întocmit un raport, pe care l-au trimis pontifului și în urma căruia l-au condamnat pe Antoninus, obligându-l să renunțe la administrarea diocezei sale. Datorită acestor mărturii ale Sfantului Augustin, știm faptul că apelul și procesul s-au desfăşurat conform canoanelor sinodului de la Sardica din 343, introdus temporar în provinciile africane până la sinodul din Cartagina din 419. A se vedea Johannes Divjak La question des appels a Rome d apres la Lettre 20 d Augustin, în volumul Vie conciliaire et collections canoniques en Occident, IVe - XII siecles, coord. Charles Munier, Variorum Reprints, Londra, 1987.

24 Dominique Moreau, op.cit., p. 375.

25 Jean Gaudemet, op.cit. p. 305.

${ }^{26}$ Ibidem.p. 135.

27 Înainte ca procesul să fie trimis înaintea împăratului în vederea obținerii sentinței, judecătorul comunica celor două părți raportul întocmit, iar în cazul unei neînțelegeri apelul era înaintat înainte de sentința finală. Școala critică a lui Giovanni Bassiano și Azzonis înclină să favorizeze reverificarea sa luând în calcul premisa că judecătorul poate întocmi un raport fals, o decizie incorectă pentru ca aceasta să fie trimisă forului imperial. Ibidem, p. 91.

${ }^{28}$ Puterea temporală a Pontifului Roman este conexată de asumarea a trei titulaturi: potestas, auctoritas și primatus, primele două fiind specifice împăraților. Acestea provin din dreptul public roman. În timpul Republicii, potestas era termenul juridic care desemna puterea magistraţilor, în timp ce auctoritas desemna autoritatea senatului. Odată cu instaurarea Principatului de către Octavianus Augsutus, 27 î.Hr., acesta preia ambele titulaturi: potestas și auctoritas, aşadar noua formă de guvernare limitează puterea Senatului (a reprezentaților poporului roman) în favoarea unei singure persoane. Acest fapt va fi caracteristic epocii imperiale până în 476 d.Hr.

În schimb, termenul juridic de Primatus este necunoscut antichității clasice, fiind prezent doar în vocabularul canonic din antichitatea târzie. El provine de la termenul mai vechi de Principatus și desemnează primatul episcopului într-o circumscripție ecleziastică. Încă din secolul al IV-lea, mai multe texte oficiale afirmă Primatul Bisericii Romane. Îl găsim formulat în canonul 6 al conciliului de la Nicaeea și în Novela 17 a împăratului Valentinianus al III-lea din 445. Ulterior și pontifii romani din secolul al V-lea își asumă titulatura de Primatus pentru a sublinia întâietatea lor în fața altor episcopi. A se vedea, Jean Gaudemet, op.cit, pp. 133-134.

În plus, prin asumarea celorlalte două titulaturi de potestas și auctoritas, pontifii își arogă calitatea de moștenitori a împăraților romani, care va fi afirmată de-a lungul evului mediu prin proiectele Sfântului Scaun de a revitaliza Imperiul Occidental împreună cu dreptul roman.

29 În limba latină appellatio, (appello) semnifică recursul unui litigant către o curte de judecată superioară atunci când judecata unei (curți) inferioare nu i-a fost favorabilă. 
Tudor STEFĂNESCU, DREPTUL LA APEL CĂTRE SFÂNTUL SCAUN, AL INSTITUȚIILOR ECLEZIASTICE DIN TRANSILVANIA, ÎN SECOLUL AL XIII-LEA

Din punct de vedere istoric, amintim că în perioada Republicii Romane, apelul nu era cunoscut sub forma unei legislații structurate. Din perioada Imperiului însă, apelul este introdus în procese ca o procedură extraordinară (cognitio extra ordinem), ca un remediu împotriva abuzurilor. În secolul IV d.Hr. el este reformat, gradual și în cele din urmă, sub domnia împăratului Iustinian, appellatio s-a dezvoltat într-o instituție generală aplicabilă tuturor proceselor, atât în chestiuni civile, cât și penale, cu excepția sentințelor emise de prefectul praetor, de către funcționari administrativi sau împărat.

Din perioada imperiului, appellatio a devenit sinonim cu termenul de provocatio, însă ele aveau caracteristici juridice diferite. La origine, appellatio însemna o cerere de ajutor adresată unui magistrat în timpul procesului de către un litigant. În schimb, în vremurile mai timpurii, termenul de provocatio se referea exclusiv la supunerea cazului judecății senatului și era aplicat doar proceselor penale. Dat fiind faptul că împărații romani (din a doua jumătate a secolului al II-lea d.Hr.) au preluat din atribuțiile senatului și ale magistraților, appellatio și provocatio au ajuns să se confunde.

Pe de altă parte, în secolele al IV-lea și al V-lea, dreptul la apel a fost asimilat și integrat în canoanele emise de conciliile ecumenice datorită faptului că oferea posibilitatea unei judecăţi mai obiective și corecta nedreptatea sau abuzurile judecătorului eclesiastic. A se vedea: Adolf Berger, Encyclopedic dictionary of Roman Law, Ed.American Philosophical Society, Philadelphia, 1991 pp. 364-365 și Dictionaire du droit canonique. Tome troiseme coordonator Prof.R.Naz, Ed. Librairie Letouzey et Ane, Paris, 1942, pp. 763-772.

$3^{0}$ De la jumătatea secolului IV, criza financiară a imperiului se agravează, prin urmare împărații emit constituții prin care interzic dreptul la recurs celor care sunt condamnați pentru datorii față de fisc. Pentru mai multe detalii a se vedea: Peregami Federico, op.cit, pp. 127-157.

${ }^{31}$ Liber VII, Caput LXV II Quorum Appellationes non recipiantur: Imp.Constantinus A, ad Hieroclem: „Observare curabis ne quis homicidiarum veneficorum maleficorum adulterorum itemque eorum, qui manifestam violentiam commiserunt, argumentis coniuctus, testibus superatus, voce etiam propria vitium scelusque confesus audiatur appelans.”, Codex Iustinianus, ediție îngrijită de Paul Krueger, Berolini Publisher, Oxford, 1877, p. 709 Traducere: „(Cartea VII, Capitolul LXV: Celor cărora apelurile nu le sunt acceptate: Împăratul Constantinus A, către Hieroclem: Cu grijă observi faptul că nicio (persoană acuzată de) omucidere, otrăvire, crima, adulter sau orice altă persoană care a fost vinovată de comiterea unei violențe, care a fost acuzată prin argumente/mărturii/probe sau care prin propria sa voce a mărturisit că este vinovată nu-i va fi ascultat/acceptat apelul.)."

$3^{2}$ Antonio Padoa-Schioppa, op.cit. p. 62.

33 Liber VII, Caput LXV, Quorum Appellationes non recipiantur: „(...) Sicut enim haec ita obscurari disposuimus, ita aequum est testibus productis, instrumentis prolatis aliisque argumentis praestitis, si sententia contra eum lata sit et ipse, qui condemnatus est aut minime voce, sua confessus sit aut formidine tormentorum tentus contra se aliquid dixerit, provocandi licentiam et non denegari.” Codex Iustinianus ... p. 709 Traducerea „(Cartea VII, Capitolul LXV, Celor cărora apelurile nu le sunt acceptate: (...) Noi, oricum, dorim să fie observat faptul că justiția cere producția textelor(mărturiilor), argumente sau alte evidențe furnizate, și dacă o sentință a fost emisă împotriva unui inculpat și acesta nu își mărturisește vinovăția sau fiind înfricoşat de tortură, spune orice împotriva sa, lui nu îi este negat apelul."

34 În privința Școlii din Bologna, Irnerius a acceptat apelul împotriva sentințelor de condamnare ale infracțiunilor grave, chiar dacă existau probe. $\mathrm{Cu}$ toate acestea, el pornea de la premisa conform căreia mărturiile nu reprezentau o probă suficient de stabilă pentru o sentință definitivă. Pornind de la Irnerius juriștii abordează în premieră chestiunea erorii probei prin mărturie, un fapt inexistent în dreptul antic roman. 
Tudor STTEFĂNESCU, DREPTUL LA APEL CĂTRE SFÂNTUL SCAUN,

Istoricul Schioppa identifică textul lui Irnerius în acest fel: „vere victis atque confessis hoc beneficium non datur, quia etsi convicti sunt et tamen si resistendum putaverint vel terrore tormentorum confessi, ab huiusmodi consilio (auxilio?) non excluduntur?” A. Padoa-Schioppa Ricerche sull appello..., p. 74.

35 În Evul Mediu, printre primele interpretări ale acestei legi le observăm în Decretalele False ale episcopului Isidor din Sevilia scrise între 847 şi 852, având scopul de a legitima autoritatea locală a episcopului și cea universală a pontifului. Așadar pentru a-i avataja pe episcopi în fața autorităților seculare, Decretalele menționează faptul că niciunei persoane nu îi este exclusă dreptul la apel către Sfântul Scaun, deci exercitarea apelului este liberă. Deretalele lui Isidor vor avea o influență imensă asupra lui Gratianus și a Școlii de Drept din Bologna în secolul al XII-lea, întărind autoritatea dreptului la apel. A se vedea: Jean Gaudemet, op.cit. p. 186 și Dictionaire du droit canonique... p. 768.

${ }^{36}$ În virtutea Primatului Suveranului Pontif, sentințele acestuia sunt inapelabile, având o substanță sacră. De asemenea Suveranul Pontif este cel care deleagă puterea judecătorească episcopilor.Aceste principii sunt afirmate în capitolele XX și XXVIII din scrisoarea Dictatus Papae D.P, XX: „... nicio persoană să nu îndrăznească să îl condamne pe acela care face apel la Scaunul Apostolic.” și, de asemenea, în XXVIII „... Sentințele sale (ale pontifului) nu pot să fie retrase de către nicio persoană, doar el însuşi le poate retrage”. A se vedea, Jean Gaudemet, op.cit. pp. 308-309.

37 Cod. Liber VII, Caput 69. 1 „Si de monumentaria possessione fuerit appellatum: Cum de possessione et eius momento causa dicatur, etsi appellatio onterposita fuerit, tamen lata sententia sortiatur effectum. Ita tamen possessionis reformationem fieri oportet, ut integra omnis proprietatis causa servetur.” Codex Iustinianus... p. 713 Traducere: „(Cartea VII, Capitolul 69. Unde apelul este înaintat (în chestiunea) posesiunilor temporale: Când posesiunile temporale sunt judecate în proces, chiar dacă apelul este înaintat, sentința va avea loc. Chestiunea posesiunii va fi decisă, pentru ca proprietatea în toată integritatea ei să rămână intactă)”.

38 Antonio Padoa-Schioppa, La Giustizia Medievale Italiana. Dal Regnum ai Comuni, Fondazione Centro di Studi sull Alto Medioevo, Spoleto, 2015, p. 74.

39 Ibidem, p. 75.

$4^{0}$ Procedura se numea episcopalis audientia, care definea limitele juridice în care episcopul avea dreptul de a judeca procesul, care era asemănătoare mai mult unei medieri conform legii creștine (ad legem christianam), nu unui proces clasic. Din anul 408, în urma reformei lui Theodosius al II-lea procesele eclesistice sunt judecate exclusiv de către episcopi, aceștia având dreptul de a emite sentințe definitive A se vedea: Lucio de Giovanni, op.cit., p. 131.

${ }^{41}$ Istoricul Schioppa identifică în lucrarea lui Piacentinus, Summa Codicis, în capitolul De episc.audientia următoarea afirmație: „poro(meo iudicio) hodie a sententia episcopi appellabitur, et ad civilem iudicem causa transferetur, maxime si episcopus causam pecuniariam sententiavit”. A se vedea: A. P.Schioppa, Ricerche sul ‘appello ... p. 89.

${ }^{42}$ Din nou istoricul citat mai sus identifică în opera lui Azonis, Lectura Codicis afirmația: „non subiecti eligerunt episcopum ut iudicem: tunc non potest appellari”. Ibidem, p. 91.

$43 \mathrm{O}$ analiză amănunțită a contribuțiilor lui Alexandru al III-lea legislației apelului găsim întro altă lucrare a autorului citat mai sus, Idem, Studi sull diritto canonico medievale, Fondazione Centro di Studi sull Alto Medioevo, Spoleto, 2017.

44 Titlul de Vicarius Christi pe care Inocențiu al III-lea și-l arogă semnifică statutul său metauman, fiind reprezentant ai lui Hristos pe Pământ. Din această poziție, el își asumă rolul de judecător suprem, intervenind în chestiunile temporale şi spirituale pentru a judeca şi corecta păcatele. În acest sens invocă principiul canonico-teologic ratione pecati (rațiunea păcatului) ce implică trei 
Tudor STEFĂNESCU, DREPTUL LA APEL CĂTRE SFÂNTUL SCAUN, AL INSTITUȚIILOR ECLEZIASTICE DIN TRANSILVANIA, ÎN SECOLUL AL XIII-LEA

valențe: în primul rând o valență juridică foarte importantă, dat fiind faptul că păcatul este considerat infracțiune și trebuie sancționat. În al doilea rând, sancţionarea păcatului, ce implică asumarea poziției de judecător suprem din partea pontifului, are și o dimensiune teologică esențială deoarece prin corectarea păcatului omul se apropie de Dumnezeu. În al treilea rând principiul ratione peccati implică şi o dimensiune etică, deoarece își propune corectarea și îmbunătățirea comportamentului societății, conform moralei creștine. Pentru mai multe detalii privind eclesiologia inocentină și chestiunea juridică a păcatului recomandăm lucrarea lui Piero Bellini, Potestas Ecclesiae circa temporalia. Concezione tradizionale e nuove prospettive, Ed. Officium Libri Catholici, Roma, 1968, pp. 24-25.

45 Gábor Barabás, Delegated Papal Jurisdiction and the Religious Orders in the Diocese of Veszprem in the First Half of the $13^{\text {th }}$ Century, articol publicat în volumul Specimina Nova Pars Prima Sectio Medievalis VIII, Pecs, 2015.

${ }^{6}$ Pentru o viziune generală privind implicarea Sfântului Scaun în spațiul transilvănean recomandăm lucrarea lui Șerban Turcuș, Sfântul Scaun și românii în sec. XIII, Editura Enciclopedică București, 2001.

47 „Decembrie 14, 1199, Roma Inocențiu al III-lea oferă dreptul episcopului Transilvaniei să apeleze la Sfântul Scaun "în pricinile cu arhiepiscopul de Strigoniu, prepozitul de Sibiu și clericii saşi”. Documente privind Istoria României, veacul XI, XII și XIII, C. Transilvania, Vol. I, (10751250), ed. Academiei Republicii Populare Române, 1951, documentul nr.25, p. 25,26.

48 În acest articol ne referim la următoarele instituții eclesiastice:

1. arhiepiscopia: instituția eclesiastică ce cuprinde mai multe episcopii. În Evul Mediu arhiepiscopul se poziționează ierarhic între episcop și Suveranul Pontif. În regatul maghiar, arhiepiscopului de Kalocsa îi revenea atribuția de a-i încorona pe monarhi, el având titlul de legatus natus (legat pontifical).

2. episcopia: instituție eclesiastică cu rol administrativ-teritorial. În Evul Mediu episcopul era ierarhul care administra un teritoriu (dioceză) atât în privința chestiunilor spirituale, cât și temporale legate de disciplina ecleziastică și guvernarea diocezei. Sediul episcopului este în biserica catedrală, numită astfel deoarece adăpostește catedra acestuia (aşa numit tronul episcopului).

3. capitlul catedral: colegiu de canonici, ataşat unei catedrale. În Evul Mediu, canonicii dintr-un capitlu reprezintă clerul superior din acea dioceză. Lor le revin responsabilităţi atât în efectuarea serviciului liturgic în catedrală, cât și în administrarea diocezei, alături de episcop. În secolul al XIII-lea, pe care îl avem în vedere, canonicii din capitlu aleg episcopul. In cazul vacanței scaunului episcopal, aceștia preiau atribuțiile administrative ale diocezei.

4. prepozitura: instituția eclesiastică alcătuită din clerici regulari, în fruntea căreia se află un prepozit. În Transilvania medievală amintim de prepozitura Sibiului, care cuprindea clerul săsesc și care se afla totuși în afara jurisdicţiei episcopului Transilvaniei. În articol vom aminti și de prepozitura Aradului.

5. ordinele monahale: comunităţi de monahi (laici și clerici) organizate din punct de vedere instituțional. Ordinul are o organizare internă proprie, bazată pe reguli monastice: spre exemplu Regula Sf.Benedict. Ordinele monahale sunt ierarhizate şi au o guvernare autonomă. Monahii trăiesc în mănăstiri independente financiar, având astfel posibilitatea să se izoleze de aglomerări urbane sau rurale pentru a se dedica vieții spirituale. În articolul de față ne referim la Ordinul Benedictin și Ordinul Cistercian. Reținem că teritoriile mănăstirilor benedictine şi cisterciene devin exempte, ceea ce înseamnă că se situează în afara exercițiului juridic al instituțiilor eclesiastice locale, suspunându-se direct abației mamă, care la rândul ei se află sub jurisdicția Scaunului Apostolic. 
Tudor STEFĂNESCU, DREPTUL LA APEL CĂTRE SFÂNTUL SCAUN,

6. ordinele mendicante: ordine religioase centralizate a căror membri sunt și laici şi care trăiesc organizați în funcție de anumite reguli: spre exemplu Regula Sf.Augustin sau Regula Sf. Francisc ce impun jurământul sărăciei, a castității și ascezei urmând exemplul Apostolilor. O particularitate a mendicanților este faptul că se dedică activităților de evanghelizare în rândul populației urbane în special. Așadar ei își amplasează conventele (așezămintele) în mijlocul orașelor. În articolul de față, noi ne referim la apelurile Ordinului Dominican, atestat în Transilvania din prima jumătate a secolului al XIII-lea.

Pentru mai multe detalii despre aceste instituții medievale recomandăm Dictionaire de Droit Canonique, coord.R.Naz, ed. Librairie Letouzey et Ane, Paris, 1942, Dizionario degli Istituti di Perfezione, vol.I, coord. Guerrino Pellicia şi Giancarlo Rocca, edizioni Paoline, Roma, 1974 şi Enciclopedia Treccani, 2013, enciclopedie online http://www.treccani.it/ enciclopedia/cattedra_\%28Enciclopedia-dell\%27-Arte-Medievale\%29/.

49 Serban Turcuş, Un processo transilvano alla corte dell ponteficia, articol publicat în volumul Medieval and Early Modern Studies for Central and Eastern Europe, ed. Universității, „Alexandru Ioan Cuza”, Iași, 2009.

$5^{\circ}$ „3 Mai 1205, Roma (Sf.Petru), Inocențiu episcopul, robul robilor lui Dumnezeu, către venerabilul frate arhiepiscopul de Calocea, mântuire și binecuvântare apostolică. Am fost înștiințați din partea ta că pe pământul fiilor cneazului Bela se află un oarecare episcopat pe care cum nu e supus niciunei mitropolii, vrei să-l aduci la ascultarea scaunului apostolic și să-l așezi sub jurisdicția bisericii din Calocea, dacă noi îți dăm învoirea noastră în această privință... „Documente privind Istoria României, veacul XI, XII și XIII, C.Transilvania, Vol. I, (1075-1250), Ed. Academiei Republicii Populare Române, 1951, doc. nr.47, p. 29.

${ }^{1}$ Ibidem, p..29.

52 Ibidem, doc.nr 45, p. 28.

53 Kenneth Pennington, Representation in Medieval Canon Law, articol publicat în revista „The Jurist”, nr.64, an 2004, p. 362.

54 Pentru mai multe detalii monografice despre episcopia Transilvaniei, consultă lucrarea lui Adinel Ciprian Dincă, Instituția episcopală latină în Transilvana medievală: sec XI, XII$X I V$, Cluj-Napoca, 2008.

55 „Decembrie 14, 1199, Roma Inocențiu al III-lea oferă dreptul episcopului Transilvaniei să apeleze la Sfântul Scaun "în pricinile cu arhiepiscopul de Strigoniu, prepozitul de Sibiu și clericii sași”. DIR... vol.I, doc.25, p. 25,26.

„Iunie 19, 1205, Roma(Sf.Petru) - Episcopul de Pecs apelează la Sfântul Scaun pentru pentru a primi iertarea. Papa Inocențiu al III-lea poruncește episcopului de Cenad și abatelui de Stekdor să primească dezvinovățirea canonică a episcopului Călan de Pecs.” Ibidem, doc.48, p. 30.

„Octombrie 29, 1219, Viterbo - Desideriu, episcopul Cenadului, apelează la Sfântul Scaun pentru a rezolva situația precară a bisericii din Itebea, aparținând ordinului călugărilor negri(Benedictini), aflată în dieceza Cenadului. Honoriu al III-lea poruncește episcopului de Oradea și prepozitului de Alba să cerceteze situația acestei biserici pentru a lua o hotărâre.” Ibidem, doc.112, p. 169, 170.

„Decembrie 15, 1220, Roma (Lateran)- Episcopul de Cenad apelează la Sfântul Scaun în urma faptului că a fost păgubit de către episcopul de Oradea.” Ibidem, doc.116, p. 175, 176.

„Octombrie 22, 1232, Anagni - Rainald, episcopul Transilvaniei trimite o scrisoare Sfântului Scaun aducând la cunoștință faptul că nu s-a judecat procesul cu abatele şi conventul mănăstirii din Cluj, din pricina faptului că această instituție nu a avut niciun reprezentant la judecată. Grigore al IX-lea îl însărcinează pe Iacob, legatul papal să rezolve conflictul între cele două părți: episcopul Transilvaniei și conventul mănăstirii Cluj.” Ibidem, doc.217, p. 258. 
„Noiembrie 8, 1235, Viterbo - Rainald, episcopul Transilvaniei a înaintat o plângere la Sfântul Scaun împotriva decanului și preoților din Țara Bârsei. Grigore al IX-lea poruncește episcopului Cumanilor să cerceteze conflictul dintre cele 2 instituții și să ofere un răspuns în vederea redeschiderii procesului." Ibidem, doc.238.

„Noiembrie 13, 1235, Viterbo - Rainald, episcopul Transilvaniei a înaintat o plângere împotriva mai multor prelați din dieceza Transilvaniei.Grigore al IX-lea poruncește episcopului Cumaniei și prepozitului de Cenad să cerceteze acest caz." Ibidem, doc.239, p. 284, 285.

„Decembrie 18, 1235, Viterbo - Rainald, episcopul Transilvaniei înaintase o plângere împotriva abatelui și conventului mănăstirii din Cluj. Grigore al IX-lea poruncește episcopului cumanilor și prepozitului de Cenad să cerceteze pricina dintre cele 2 instituții.” Ibidem, doc.240, p. 288.

„Aprilie 2o, 1255, Roma (Lateran) - Papa Alexandru al IV-lea aprobă cererea episcopului Transilvaniei privitoare la mărirea veniturilor bisericii din Alb-Iulia.”, DIR... vol II, sec XIII (1251-1300), doc.13, p. 14.

„Martie 13, 1277, Viterbo - Papa Ioan al XXI-lea poruncește episcopului de Oradea să cheme pe Nicolae prepozitul bisericii transilvane, episcop ales de Strigoniu în fața Scaunului Apostolic" Ibidem, doc.205, p. 188. Aici adăugăm o observație de ordin filologic: În compendiul de documente citat mai sus sunt menționate 2 apeluri ale instituției ecleziastice a cumanilor sub numele de capitlul cumanilor. Noi opinăm că este vorba de o greșeală filologică, deoarece nu a existat un capitlul al cumanilor, instituția la care se referă documentul probabil fiind episcopia cumanilor.

„1) Iulie 7, 1218, Roma - Capitlul cuman apelează la Sfântul Scaun pentru a primi dreptul de a împărți dijmele pentru veșminte alături de capitlurile bisericilor catedrale vecine. Honoriu al III-lea poruncește arhiepiscopului de Kalocsa să ia măsurile necesare pentru a face dreptate capitlului cuman.” Ibidem, doc.110.

„2) Iulie 7, 1218, Roma - Capitlul cumanilor apelează la Sfântul Scaun pentru rezolvarea neînțelegerilor din biserici privind situația alimentelor canonicilor. Honoriu al III-lea poruncește arhiepiscopului de Kalocsa să cerceteze neînțelegerile din capitlul cumanilor” Ibidem, doc.111.

${ }^{56}$ Ibidem, doc. 112, p. 169.

57 A se vedea: DIR... vol I, doc. nr.48.

${ }^{8}$ Ibidem, doc.nr.141, p. 196.

59 Ibidem. doc. 217, p. 257.

${ }^{60}$ Reiterăm articolul citat: Serban Turcuş, Un processo transilvano alla corte dell ponteficia... ar trebui să fie indicațiile bibliografice ale acestui articol.

${ }^{61}$ Pentru mai multe detalii privind evoluția acestei instituții în regatul maghiar medieval recomadăm lucrarea lui Kiss Gergely, Contribution a l'evolution des chapitres dans la Hongrie medievale, articol publicat volumul Specimina Nova Pars Prima, Sectio Medievalis I, Pecs, 2001, pp. 109-120.

62 Kenneth Pennington sugerează că funcțiile instituției capitlului au fost reglementate de primele culegeri importante de canoane, asemeni unei corporații. „The first body that the jurists of the Ius commune examined in detail, was not surprisingly, the cathedral chapter. When they discussed the relationship between the bishop and his chapter, they created a jurisprudence of corporate thought that incorporated a head, a body, and an institution, the cathedral chapter. Their jurispridence created and established norms that regulated the relationship between the members. Perhaps most importantly for our consideration, the jurists conceived of the chapter as a body that also reppresented a geographic unit, the diocese." Keneth Pennington, Representation in Medieval Canon Law, p. 363. 
De asemenea, continuă Pennington, din secolul al XII-lea există o tendință în gândirea canoniștilor de a acorda importanță capitlului, ca reprezentantă a vocii a clerului local: o observăm în rezoluțiile conciliului al III-lea Lateran și în operele lui Uguccione și Laurentinus. Spre exemplu, în vederea organizării conciliului al IV-lea Lateran, Inocențiu al III-lea a informat membrii capitlurilor să își trimită reprezentații. Ibidem, pp. 370-373.

A se vedea, de asemenea: Brian Tierney, Foundations of the Conciliar Theory, Cambridge, 1955, pp. 98-140.

63 În schimb, consolidarea tendințelor hierocratice tensionează aceste drepturi și evidențiază prevalența deciziei pontificale în fața alegerilor locale ale capitlurilor, mai ales, începând cu pontificatul lui Inocențiu al IV-lea. Totuși încă din 1216 observăm demnitari eclesistici care nu acceptau dreptul capitlurilor de a participa la concilii. Așadar în același an, când arhiepiscopul din Sens refuză participarea reprezentaților capitlului din același oraș la adunarea sinodului provincial, aceștia înaintează apelul către instanța pontificală. Keneth Pennington, op.cit., p. 8.

64 Din punct de vedere cronologic, le enumerăm în felul următor:

„Noiembrie 17, 1226, Roma - Capitlul bisericii din Cenad apelează la Sfântul Scaun pentru a primi dreptul de mări prebendele unor canonici din «veniturile capelelor diecezei Cenadului», care din cauza sărăciei, nu mai slujesc în biserica lor... ” DIR..., vol. I (10751250), doc.183, p. 227

„Decembrie 23, 1232, Anagni - Canonicii bisericii din Oradea, Alexandru şi Ioan apelează la Sfântul Scaun pentru a rezolva conflictul lor cu abatele Benedict, lector excomunicat din Strigoniu, ales în mod abuziv, care le-a confiscat toate bunurile. Grigore al IX-lea poruncește lui Iacob, legatul papal să cerceteze abuzurile lui Benedict.” Ibidem, doc.218, p. 259

„Iulie 11, 1243, Anagni - Capitlul apelează la Sfântul Scaun pentru a-l numi pe episcopul Oradei păstor în biserica vacantă din Gyor. Inocențiu al IV-lea poruncește episcopului de Nitra, prepozitului bisericii Sf.Toma din Strigoniu și magistrului Petru canonic de Kalocsa să îndeplinească această cerere". Ibidem, doc.276, p. 324

„Septembrie 18, 1247, Lyon - Episcopul, prepozitul și capitlul bisericii din Kew apelează la Sfântul Scaun pentru a primi aprobarea de a muta în alte mănăstiri (...) scaunul episcopal, deoarece ținutul lor a fost pustiit de tătari. Papa Inocențiu al IV-lea poruncește arhiepiscopului de Calocea, episcopilor Transilvaniei și Cenadului să cerceteze adevărul și transmită rezultatul cercetărilor." Ibidem, doc.286, p. 333

„Iunie 18, 1282, Orvieto - Papa Martin al IV-lea poruncește arhiepiscopilor de Calocea și Bacs și episcopilor de Sirmiu și Cenad să cerceteze dacă alegerea lui Toma ca episcop de Oradea s-a făcut în chip canonic", DIR....vol.II, sec.XIII (1251-130o), doc.nr.272, p. 242.

65 Pentru detalii referitor la proces, a se vedea: DIR... vol.I, doc. 218, p. 259.

66 Observăm din descrierea procesului că sentința definitivă a fost amânată în primul rând din cauza unei legislații a apelului foarte permisivă. Ne referim în special la faptul că susținătorii lui Benedict, chiar dacă au fost excomunicați au avut dreptul de a revoca decizia excomunicării prin înaintarea căii de atac. Așadar putem concluziona că la jumătatea secolului XIII, respectiv în 1232, orice sentință a excomunicării putea fi revocată, ceea ce este un aspect foarte important.

${ }^{67}$, ,...) Iar pentru ca să nu se întâmple ca, datorită diversiunilor spre marea pagubă a bisericii din Oradea cauza principală să sufere amânare, am hotărât să încredințăm chibzuinții tale să cercetezi și să închei această pricină potrivit canoanelor.” Ibidem, p. 260.

${ }^{68}$ A se vedea: nota 59, punctul 1).

69 A se vedea: nota 50, punctul 5). 
Tudor STEFĂNESCU, DREPTUL LA APEL CĂTRE SFÂNTUL SCAUN, AL INSTITUȚIILOR ECLEZIASTICE DIN TRANSILVANIA, ÎN SECOLUL AL XIII-LEA

${ }^{70}$ Convocarea sinodului de către legatul Filip de Fermo a avut ca scop principal corectarea insuficiențelor de care suferea organizarea Bisericii maghiare și, de asemenea, corectarea comportamentului inadecvat al clerului și monarhului. Acest sinod reprezintă cel mai vizibil instrument prin care dreptul canonic după Conciliul Lyon II este asimilat în regatul maghiar. În privința dreptului la apel, canoanele sinodale menționează libertatea tuturor litiganților de a uzita de recurs alături de pedepse pentru cei ce îl blochează. Pentru detalii recomandăm lucrarea lui Șerban Turcuș, Sinodul General de la Buda (1279), ed. Presa Univesitară Clujeană, Cluj-Napoca, 2001.

${ }^{71}$ „Ianuarie 12, 1223, Roma - Magistrul Ordinului Fraților Casei Teutonilor închinate Sfintei Marii apelează la Sfântul Scaun pentru numirea unui decan sau arhipresbiter pentru clericii din Țara Bârsei. Honoriu al III-lea îl însărcinează pe episcopul de Agria cu rezolvarea acestei chestiuni.” DIR,... vol. I, doc.nr.140, p. 195.

„Decembrie 12, 1223, Roma - Magistrul Ordinului Fraților Casei Teotonilor închinate Sfintei Marii apelează la Sfântul Scaun pentru a interveni pe lângă regele maghiar care a încercat să-și extindă propria jurisdicție asupra lor. Honoriu al III-lea îi poruncește arhiepiscopului de Strigoniu să îl oblige pe rege să își retragă pretențiile asupra Țării Bârsei sau să nu le recunoască”, Ibidem, doc.nr.146.

„Iunie 12, 1225, Tivoli - Ordinul Fraților Teutoni din Țara Bârsei apelaseră de mai multe ori la Sfântul Scaun datorită faptului că regele Andrei al II-lea, ignorând privilegiile acestora, i-a alungat din Țara Bârsei. Honoriu al III-lea îl sfătuiește pe regele maghiar să restituie ordinului monahal militar teritoriul ocupat și să-i despăgubească pentru nedreptățile pricinuite. De asemenea pontiful îi însărcinează pe abații de Linewel, Cârța și Igriș să cerceteze dacă monahii cavaleri depășiseră la rândul lor propriile hotare.” Ibidem, doc.nr.168.

„Aprilie 26, 1231, Roma - Magistrul Ordinului Fraților Ospitalieri Sfintei Marii a Teutonilor înaintează un apel la Sfântul Scaun cerând să fie depăgubiți de către regele maghiar și să li se înapoieze teritoriul. Grigore al IX-lea îl sfătuiește pe Bela al IV-lea să restituie ordinului monahal militar Țara Bârsei.” Ibidem, doc.nr.206.

„August 31, 1232, Anagni - Magistrul Ordinului Fraților Ospitalieri ai Sfintei Marii a Teutonilor apelează la Sfântul Scaun pentru a li se face dreptate în conflictul cu regele Andrei al II-lea, care i-a alungat din țara lor. Papa Grigore al IX-lea îl însărcinează pe Iacob, legatul papal să resolve conflictul cu regele maghiar.” Ibidem, doc.nr.216.

${ }^{72}$ Limitele dreptului de apel vor fi impuse, de asemenea, de catre instituțiile regulate, a căror funcționare era conditionată de recursul la instanța superioară (ad superiorem audientiam). Tentativele de limitare a recursului la o instanță superioară, care nu în mod necesar era Sfantul Scaun, se experimentează deja în primele decenii ale secolului al XII-lea, nu atât în documentele pontificale, cât în textele normative, în diplome episcopale sau în pacta nei conventiones care reglau raporturile într-o abație sau între grupuri de abații. Pentru detalii recomandăm articolul lui Guido Carboni, Appello e divieto di appello alla Chiesa Romana presso gli ordini religiosi nel XII secolo, publicat în volumul colectiv Die Ordnung der Kommunikation und die Kommunikation der Ordnungen Band 2, ed. Franz Steiner Verlag, 2012, pp. 261-277.

73 „La colpa la fanno rissalire a voi e alla curia romana. Secondo quello che dicono, voi annullate cio che essi hanno stabilito e ristabilite cio che era giustamente annullato. Tutti i piu corotti e i piu litigiosi che si trovano nel mondo laico e nel clero, e persino quelli che sono stati calcciati dai monasteri ricorrono a voi, tornando si gloriano e ostentano d 'ever trovato prottetori proprio in quelli che avrebbero dovuto essere piuttosto i loro giudici severi.", Ibidem, p. 263. 
74 „2 Aprilie 1224, Roma, Lateran, Papa Honoriu al III-lea întărește schimbul de moşii dintre Andrei al II-lea regele Ungariei și abatele și conventul din Igriş al ordinului Cistercit”. DIR... vol. I, doc.nr.149, p. 202.

75.Ibidem, doc. nr.245, p. 291.

${ }^{76}$ În același timp cu jurisdicția Sfântului Scaun, până la mijlocul secolului al XIII-lea arhiepiscopul de Esztergom își exercită simultan jurisdicția asupra lor. Aparentul paradox poate fi explicat prin faptul că arhiepiscopul de Esztergom deține funcția de legatus natus. Acest fenomen se aplică în cazul tuturor mănăstirilor, mai puțin Panolhalma. A se vedea: Kiss Gergely, The exemption of the royal Benedictine monasteries in Hungary in the $11^{\text {th }}$ $13^{\text {th }}$ century, articol publicat în volumul colectiv Specimina Nova Pars Prima. Sectio Medievalis II, Pesc, 2003 p. 32.

77 Pentru mai multe detalii despre proces, recomandăm lectura documentului în volumul DIR... vol.I., doc.234, p. 281.

${ }^{78}$ Ibidem, doc.nr.247, pp. 292-293.

79 Ibidem, doc. nr.265, p. 317.

80 „Altfel să ne înaintați pricina după ce veți fi cercetat-o îndeajuns, hotărând pentru părți un termen cuvenit, la care să se prezinte în fața noastră personal sau prin procuratori potriviți, ca să primească, cu ajutorul domnului, o sentință dreaptă.” Ibidem, p. 316.

${ }^{81}$ Ibidem, doc.133, p. 186.

82 Există mai multe apeluri din partea acestei instituții în următoarele cazuri:

„Aprilie 11, 1223, Roma - Prepozitul de Arad apelase la Sfântul Scaun în urma faptului că regele Andrei al II-lea i-a adus pagube. Honoriu al III-lea îi poruncise în primul rând arhiepiscopului de Strigoniu să rezolve conflictul dintre rege și prepozit”. Ibidem, doc. Nr 143, p. 197,198.

„Februarie 12, 1227, Roma - Prepozitul de Arad apelează la Sfântul Scaun pentru a întări înțelegerea încheiată cu subdiaconul și capelanul Ioan Capucius cu privire la prepozitura bisericii Arad. Honoriu al III-lea întărește această înțelegere”. Ibidem, doc.nr. 184, p. 227 , p. 272.

„Septembrie 26, 1235, Assisi - Prepozitul din Arad apelează la Sfântul Scaun pentru a anula sentința excomunicării emisă de arhiepiscopul de Strigoniu. Grigore al IX-lea poruncește mai multor prelați să cerceteze motivul excomunicării”. Ibidem, doc.nr.237, p. 284.

„Septembrie 18, 1247, Lyon - Episcopul, prepozitul și capitlul bisericii din Kew apelează la Sfântul Scaun pentru a primi aprobarea de a muta în alte mănăstiri ale Sf. Grigore, Sf.Dumitru și a ordinului Sf.Benedict, scaunul episcopal, deoarece ținutul lor a fost putiit de tătari. Papa Inocențiu al IV-lea poruncește arhiepiscopului de Calocea, episcopilor Transilvaniei și Cenadului să cerceteze adevărul și transmită rezultatul cercetărilor.” Ibidem, doc.nr.286, p. 333, 334. 